\title{
فاعلية برنامج مقتزح قائم على الأنشطة الغنائية في تنمية مهارات التفاعل الاجتماعي لدى طفل الروضة
}

$$
\begin{aligned}
& \text { أعداد } \\
& \text { الباحث / عبدالله فلاح المجالي } \\
& \text { إشراف } \\
& \text { المجلت العلميت لكليت رياض الأطفال ـ جامعت المنصورة } \\
& \text { المجلد الخامس ـ العدد الأول }
\end{aligned}
$$

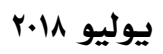




\section{فاعلية برنامج مقتزح قائم على الأنشطة الغنائية

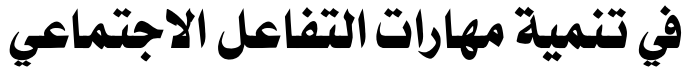 لدى طفل الروضة مهاس}

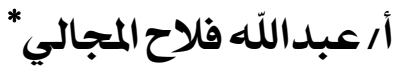

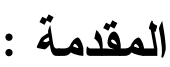

تعد مرحلة الطفولة أولى مر احل حياة الإنسان وتتخلل هذه المرحلة مرحلة

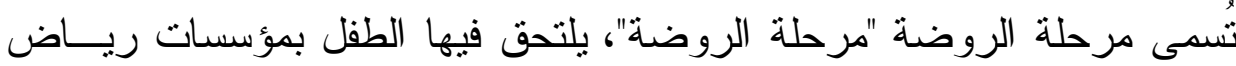

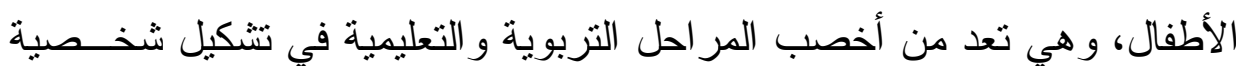

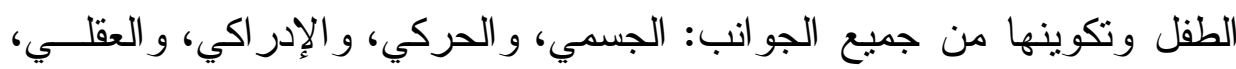

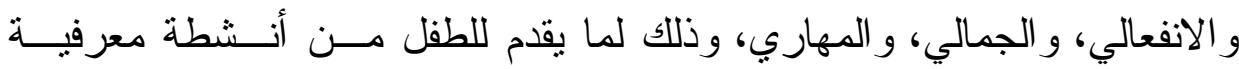

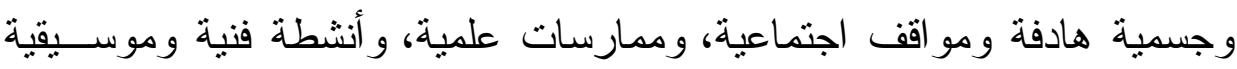

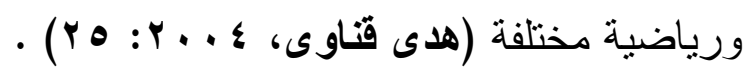

كما أن بناء شخصية الفرد يعتمد بالدرجة الأولى على السنوات الأولى من

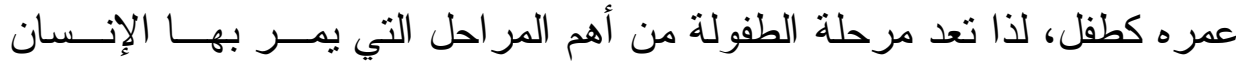

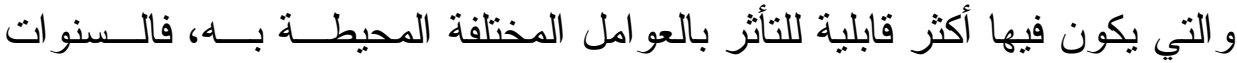
الخمسة الأولى من حياته هي التي تترك بصماتها على شخصيته وتترك أثرهـا

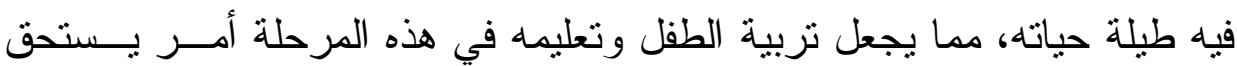

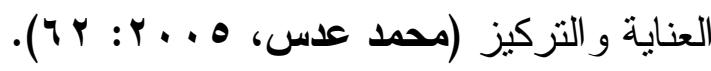

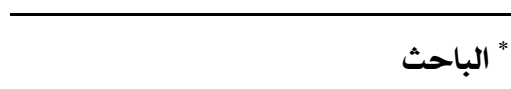




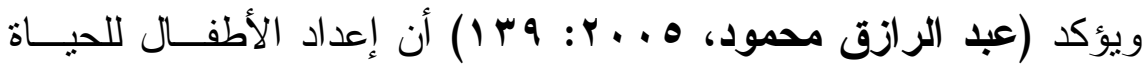

خارج أسوار الروضة، وتدريبهم على أداء المهار ات الحياتية المتطلبة منه فـي حياته اليومية، يفرض على الو اقع التعليمي وبر امجه و أسـاليب التـدريس دوراً ير اعي هذا البعد المهم في جو انب إعداد أطفالنا في دور التعليم، وهــذا الــدور الجديد يفرض على الروضة أن تسمح بظهور مو اهب الطفل عن طريق النـشـاط الحر و الموجه، ومن ثم تزويده بمهار ات منبتقة من حاجاته في جو مرح ومريح، وبيئة نشطة خالية من التعقيد .

وتؤكد مؤتمر ات الطفولة على ضرورة التتويع فــي الأنـشطة التربويـــة

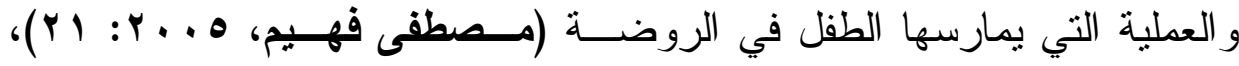
و الأنشطة التعليمية التي تقوم المعلمة بإعدادها وتتفيــذها فـــي مرحلــة ريــاض الأطفال تعتبر من العناصر الايجابية في تتمية المهار ات و إكساب المفاهيم لــدى

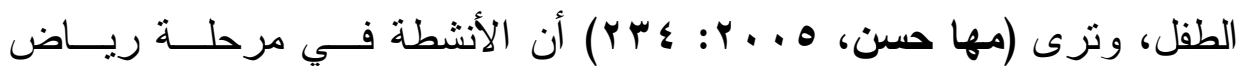
الأطفال تهدف بشكل أساسي إلى تهيئة الطفل و الإعــداد الجيــــ للتعامــل مــع متطلبات الحياة، ونشجيع روح الابتكار لدى الطفل، و إظهار مو اهبــه، وميولــه،

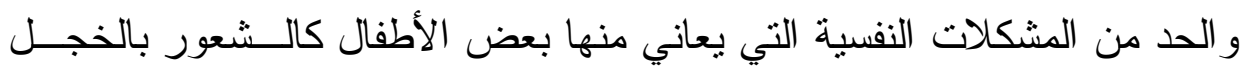

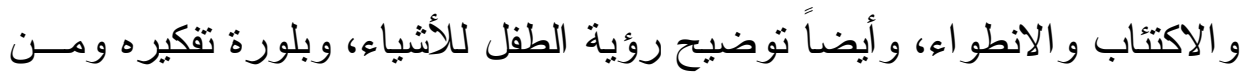
ثم زيادة نموه العقلي. وتُعد الأنشطة الموسيقية هي مجموعة الأعمال التي تقوم علــى اسـتخدام

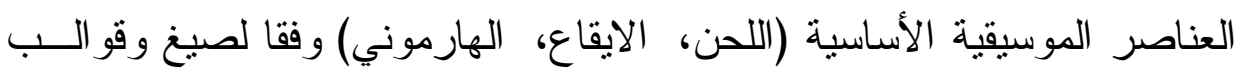
شبه محدده، و التي يمكن أن تقدم لطفل رياض الأطفال، و التي يمكن أن بيتجيب لها طفل الروضة، ويشارك فيها كخبرة جمالية لازمة لتكوينه النفسي المتكامـلـل 
المتو ازن وهي في معظمها خبرة حسية بالإضـافة أنها تهذب النفس و عن طريـق الغناء يتعلم طفل الروضة القيم و اللغة و النطق السليم، ويتعلم التعــاون، وحـبـ

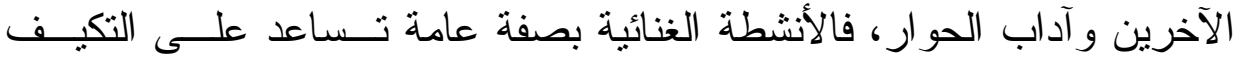

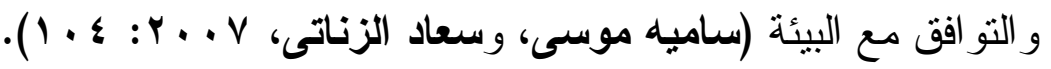

وتعد الأنشطة الموسيقية من أكثر الطرق فاعلية في تيـسير عمليــة فهــ و استيعاب دروس المو اد وغرس القيم، هذا بالإضافة إلى أن هذه الأنـشطة مــن أهم الفنون التي تلعب دور اً أساسياً في بناء شخصية المتعلم منذ مرحلة الطفولـــة المبكرة، فالأنشطة الموسيقية تنتوع ســو اء فــي مــضمونها أو أســاليبها التـي هي تستخدمها ومنها ما يؤدي على نحو فردي ومنها ما يؤدي على نحسـو جمـــاعي،

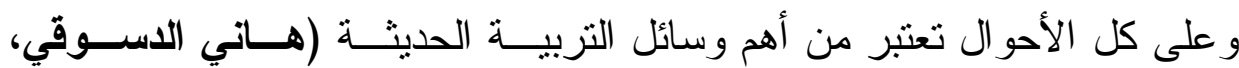

وبناء علي ما ذكر فإن لرياض الأطفال أهمية كبيرة في تهيئـة الطفـلـل

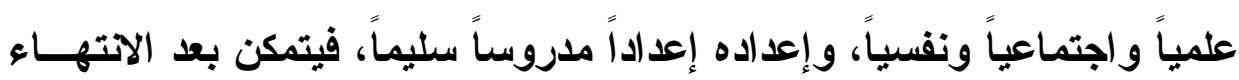

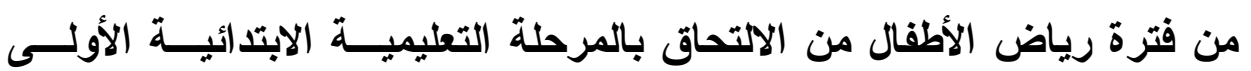
بسهولة، ويكتسب من خلالها المهارة و الخبرة التي لا يكتـسبها الطقـلـل فــي

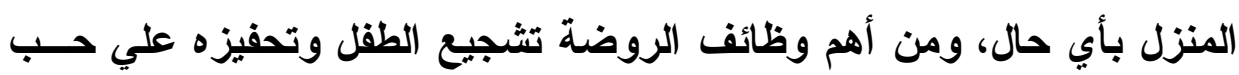

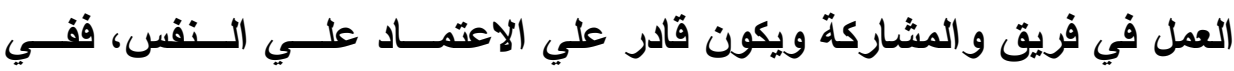

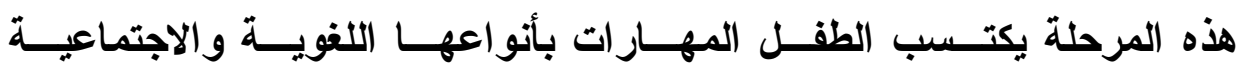
والأخلاقية، وعن طريقها سيكون الاتجاهات الإيجابية الأولية بما يخص الــتملم

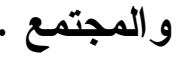


ومن هنا نجد أن تتمية مهــار ات التفاعـلـل الاجتمــاعي مثــلـ التعـــاون، و أدب التعامل مع الآخرين، الاستئذان، المــشاركة.. ذات أهميــة خاصـــة فــى

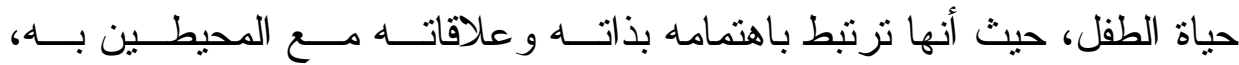

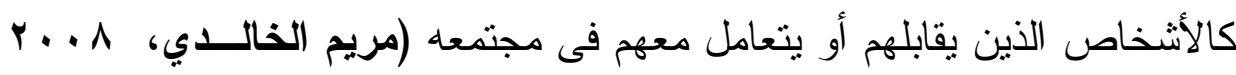
- $(7 \varepsilon-70:$

كما أن التربية الاجتماعية للطفـلـ لا تتفـصل عـن تربيتــهـ اجتماعيـاً لأن التفاعل الاجتماعى هو أسلوب الفرد في التعامل مع الآخــرين فــي الحيــاة

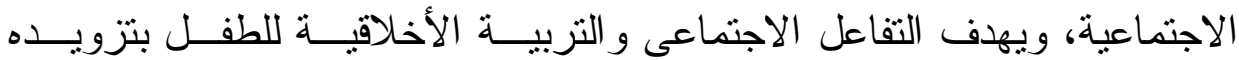
بالقيم السائدة في المجتمع التي تساعده في التكيف السليم مع بيئتـــه الاجتماعيـــة

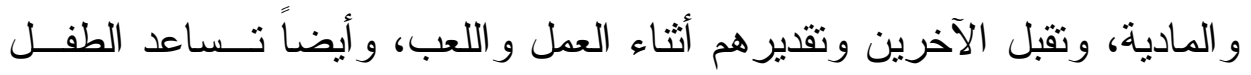
علي الموازنة بين إحساسه بالاعتمادية و إحساسه بالاستقلال ومشاركة الآخــرين و التعاون معهم وفهم الوسائل البديلة للحصول علي المطالــب (حنــان العنــــى $\cdot\left(1 \Lambda: Y \cdot V_{6}\right.$

\section{الإحساس بالمشكلة :}

انبثقت مشكلة البحث من خلال المصادر التالية :

1- مقابلة وفحص دفاتر معلمات رياض الاطفال( • سمعلمة) حيث تم ملاحظة طريقة تقديم المعلمات للبر امج و الأنشطة داخل قاعــة الــصف، و التــى اقتصرت على الأنشطة التعليمية مع قلة الاعتماد على النــشاط الغنــائى، وبسؤ ال معلمات رياض الأطفال إتضتح أن معظم ما يــتم داخـلـل قاعـــة الصف لا يتخطى حدود الأنشطة التعليمية أو بعض الأنشطة مــن أجـلـ

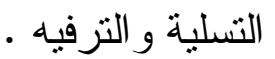


Y- اهتمام العديد من الدر اسات باستخدام الأنشطة الغنائية مثل در اســـة كُّلـل

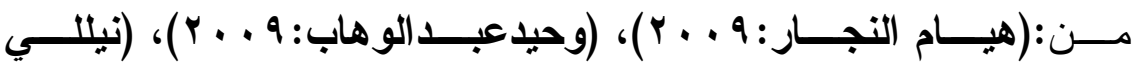

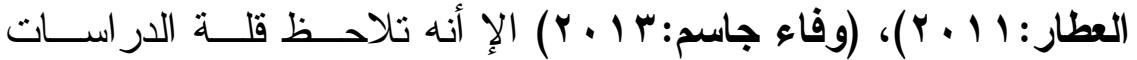

التى تتاولت النشاط الغنائي في تتمية التفاعـلـل الاجتمـــاعى لــدى طفـلـل

$$
\text { الروضة. }
$$

وتعتبر السنوات التي تسبق التحاق الطفل بالمدرسة مرحلة حاســمة فـي حياته ففي مرحلة الروضة تنتكل شخصيته لترسم الخطـــوط العريــضة لبنائـــه النفسي و العقلي و الانفعالي و الاجتماعي لذلك فان ما يتعلمه الطفل بعــــ ذا أثــر مهم وفعال في تكوينه الشخصي وبناء دعائم مستقبله، و عليه فــإن مـــا يكتـسبه طفل الروضة ينعكس على ســلوكه، فقـ طـ نلاحـــ علــى أطفالنــا ســلوكيات و استجابات لمو اقف معينة بعض هذه السلوكيات سليمة ومقبولــة مـــع مهـــار ات التقاعل الاجتماعى، وتدل على نمو نفسي سليم وبعض هذه السلوكيات مرفوضة من المجتمع وتدل على اضطر اب في النمو النفسي و الانفعالي لطفل الروضة. وتبرز مشكلة البحث من أن الطقل يولا وهو لا يعرف مهارات التفاعـل الاجتماعى التي سيخضع لها لهذا تسمى مرحلة الطفولة أحيانا بمرحلة النظام،

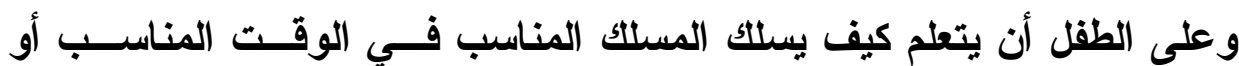
المكان المناسب أو الموقف المناسب، وأن يفهم الأسس التي تقوم عليها هــــه

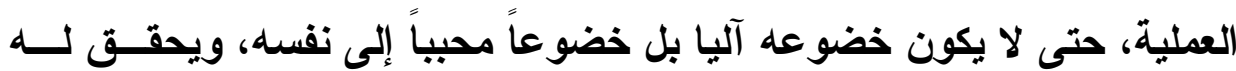
حدود الخير والثر، وحدود الحرية والفوضى ومن هنا جاءت البحث من أجـلـل

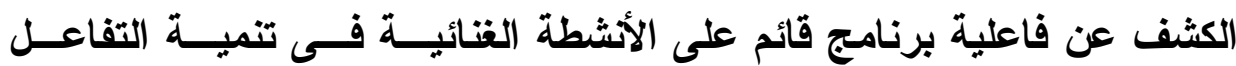
الاجتماعى لاى طفل الروضة. 
و اهتمت المناهج الحديثة بجميع أنواع الأنشطة و اعتبرتها جز ه مه مسن

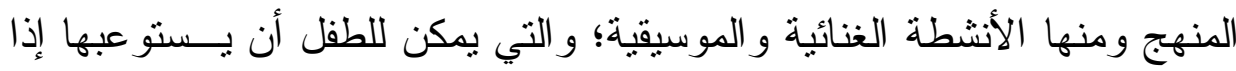

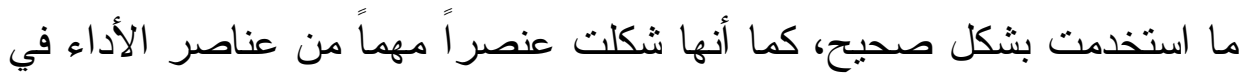
التعبير عن المشاهد الحباتية، وعنصر جوهري في البناء الروحي توقظ الثعور

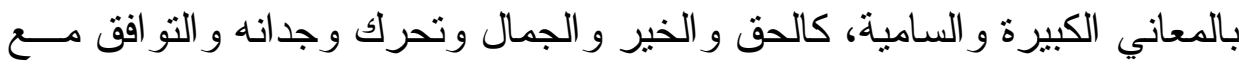

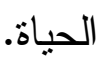

\section{تحديد مشكلة البحث :}

فى ضو ء ما نادت به توصيات المؤتمر ات ونتــائج الدراســات الــسابقة

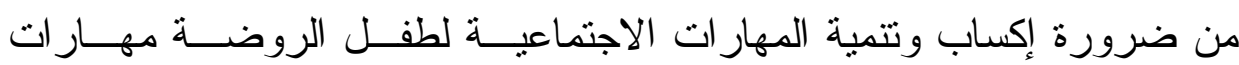

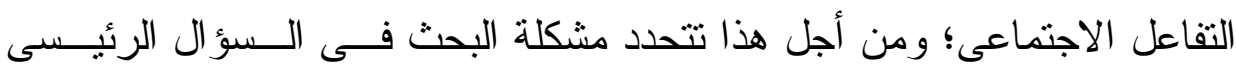

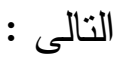

ما فاعلية برنامج مقترح قائم على الأنشطة الغنائية فى تنميــة التفاعـلـ الاجتماعى لاى طفل الروضة؟ ماعه برنج

ويتفرع من هذا السؤ ال الرئيس الأسئلة الفرعية التالية :

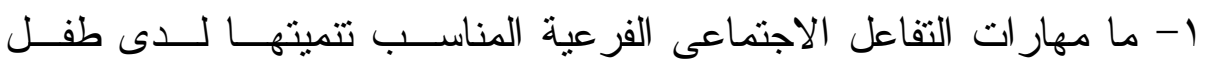
الروضة ؟ مارج

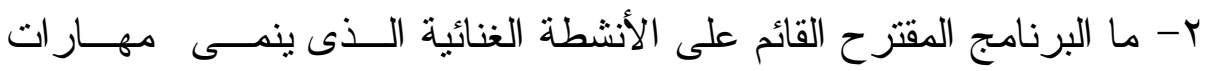

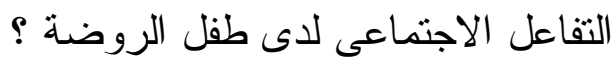

r- ما فاعلية البرنامج المقترح القائم على الأنثطة الغنائية فى تتمية مهار ات

المجلد الخامس


ـ- ما فاعلية البرنامج المقترح القائم على الأنثطة الغنائية في بقاء أنز تعلـــ

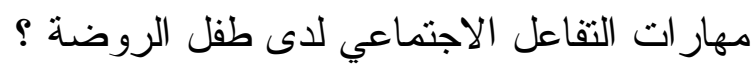

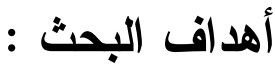

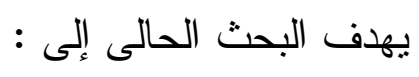

1- تحديد مهار ات التفاعل الاجتماعى الفرعية المناسب تتميتهـــا لــدى طفـلـل

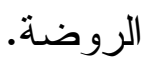

r- تحديد الأنشطة الغنائية التى تسهم فى تتمية مهار ات التفاعـل الاجتمـــى

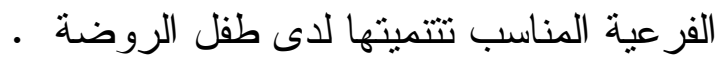

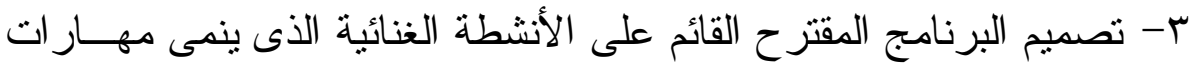

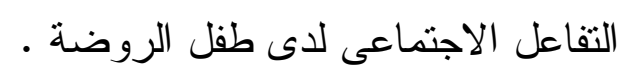

ع - قياس فاعلية البرنامج المقتر ح القائم على الأنشطة الغنائيــة فــى تتميـــة

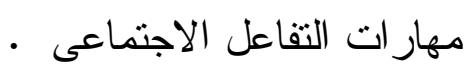

\section{فروض البحث :}

يحاول البحث الحالى اختبار صحة الفروض التالية :

1- نوجد فروق ذو دلالة إحصائية بين متوسطى درجات أطفال المجمــوعتين

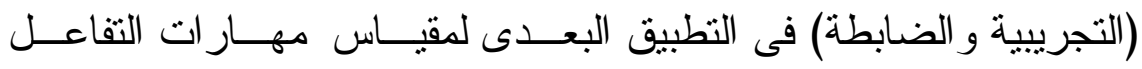

الاجتماعى لصالح المجمو عة التجريبية.

ץ- توجد فروق ذو دلالة إحصائية بين متوسطى درجات أطفــال المجموعــة

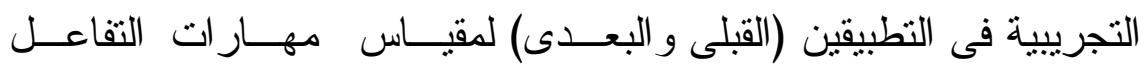

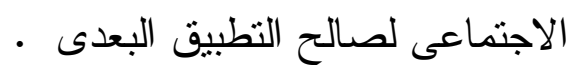


r- يحقق تطبيق البرنامج المقترح فاعلية كبيرة باستخدام مربع إيتـا ســكوير

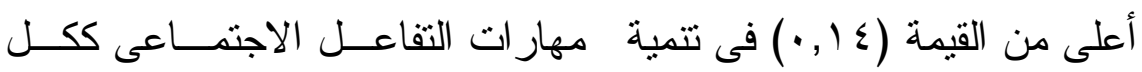
وأبعاده الفر عية لدى أطفال مجمو عة البحث.

ع- لا توجد فروق ذو دلالة إحصائية بين متوسطى درجات أطفال المجموعة

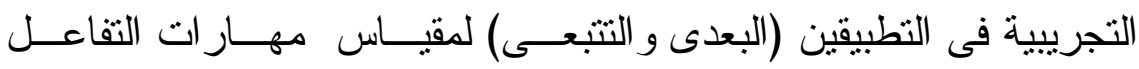

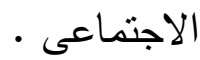

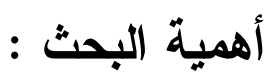
تتمتل الأهمية النظرية و التطبيقية للبحث الحالي فيما يلي:

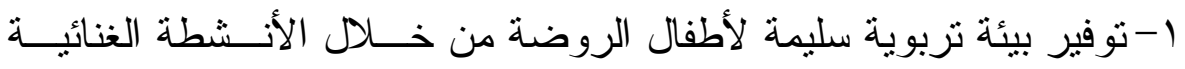
و الموسيقية المتنوعة التي تؤدي إلى تحقيق النمو السليم المتكامل. r- الرقي بالإحساس و الذوق العام لأطفال الروضة من خلال الأنشطة الغنائية

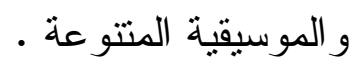

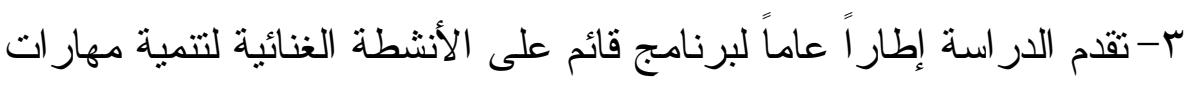

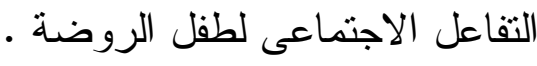

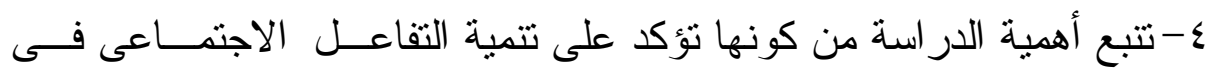

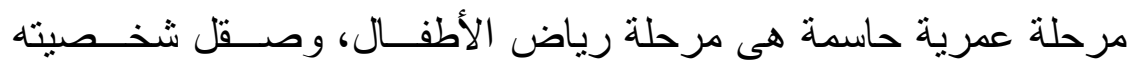
و التعبير عما بداخلها فى تلقائية و عفوية تنقق مع حاجاتهم وميولهم وتعديل

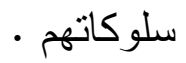
ه-تقديم مجموعة من الأنشطة الغنائية لإكساب الأطفــال مهــار ات التفاعـلـ

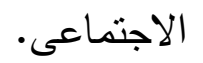


צ- التأكيد على أهمية فاعلية الأنشطة الغنائية فى تحقيق التتمية المتكاملة لطفل الروضة فى ضوء فلسفة المناهج و أهدافه .

V- التعرف على أهمية البرنامج المقتر ح خصيصًا لتتميــة مهــار ات التفاعـلـ

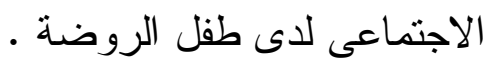

^- تقديم أسلوب تعليم يعتمد على الأنشطة الغنائية تختلــف عـن الأسـاليب المتبعة فى رياض الأطفال بتتمية التفاعل الاجتماعى .

9-تشكل هذه الدر اسة إضافة علمية للمكتبة العربية بـشكل عــام وللمكتبـة

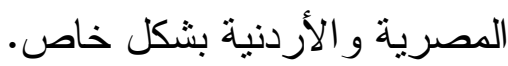

• 1-يمكن الاستفادة من هذا البحث فى توجيه أنظار المسئولين عن تخطــيط

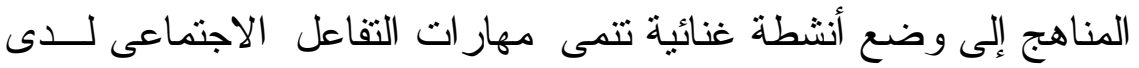

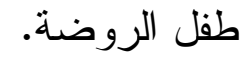
مصطلحات البحث : مصنه :

\section{: Program برنامج}

مجموعة من الخبرات التى تحتــوى علــى فلـسفة و اضــحة ومحسـددة

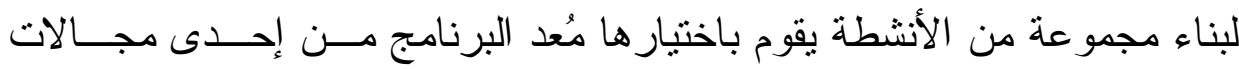

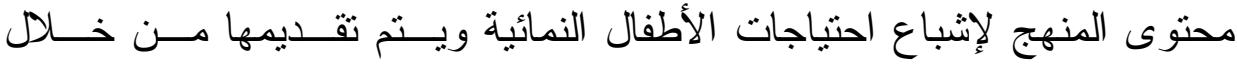

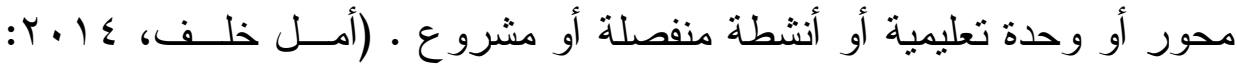

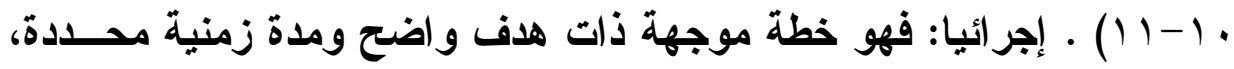

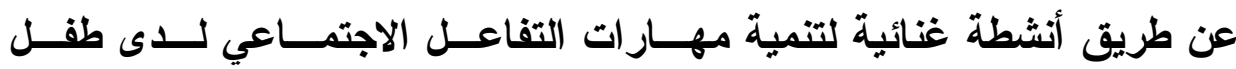

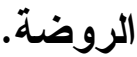




\section{r - الأشطة الغنائية :}

تعرف الأنشطة الغنائية إجر ائيًا على أنها : مجمل الأنشطة التى يمارســها الطفل مستخدمًا الموسيقى و الغناء، وبالتالى تساعد على نتمية التفاعل الاجتماعي

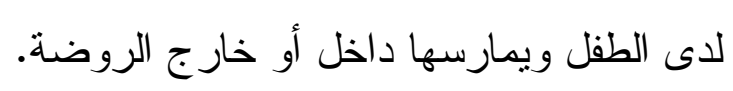
r- r التفاعل الاجتماعىى

يعرف التفاعل الاجتماعي إجر ائيًا بأنه: عملية التقاء سلوك شخـــى مــع

سلوك مغاير لله ويعتمد على الآخر ؛ حيث يؤثز ويتأثز به فى إطار من التفاعـلـل

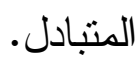

\section{منهج البحث والتصميم التجريبى : سوف يستخدم الباحث كلاً من :}

1- المنهج الوصفى التحليلى فى تحديد الإطار النظرى للبحث، وتحديــد أهـــ المهار ات الرئيسة للتفاعل الاجتماعى المناسب تتميتها لدى طفل الروضـــة

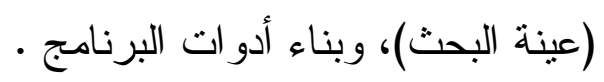

ץ- المنهج التجريبى، وذلك للتعرف على فاعلية البرنامج المقترح القائم على

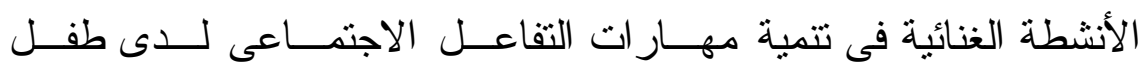

$$
\text { حدود البحثة : الروضة. }
$$

- - عينة من أطفال الروضة (المستوى الثانى) بروضــتى الــسنابل، بــر اعم

$$
\text { الطفولة. }
$$

r المجلد الخامس


- تم تطبيق البرنامج خلاد الفصل الدراسى التـاني مــن العـام الجـامعى

$$
\cdot r+19 / r \cdot 11
$$

- مهار ات للتفاعل الاجتماعى وتتشمل (التعــاون، حـب الآخـرين ، آداب

$$
\text { مواد وأدوات البحث : الحوار) • }
$$

1- قائمة مهار ات التفاعل الاجتماعى المناسب تتميتها لاى طفـل الروضـــة

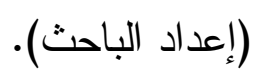

r- مقياس مهار ات التفاعل الاجتماعى الــصور لطفـل الروضــة (إعـداد

$$
\text { الباحث). }
$$

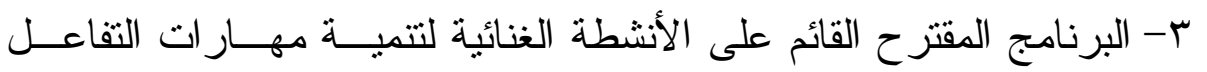
الاجتماعي لدى طفل الروضة ـ ( إعداد الباحث).

الإطار النظرى للبحث :

المحور الأول : الأششطة الغنائية :

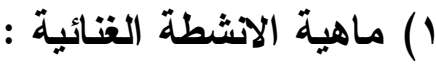

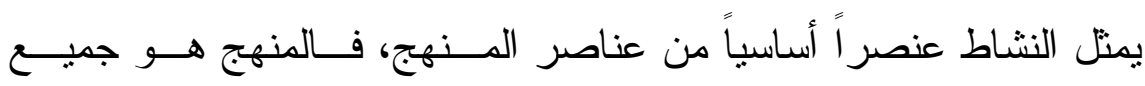

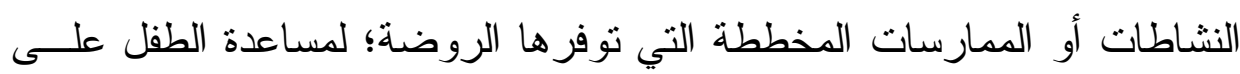
تحقيق النتاجات النعليمية المطلوبة .

وتعد أنشطة الفنون بشكل عام من العلوم التي لها تأثثير فعال في تحسسين

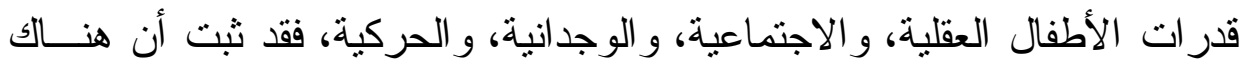

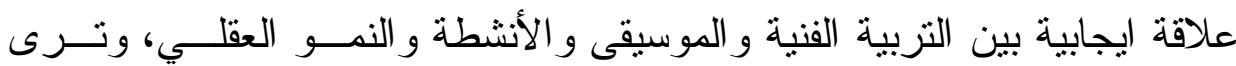


بعض الأبحاث أن الأنشطة الموسيقية يمكنها أن تكون المفتاح إلى صحة عقليــة

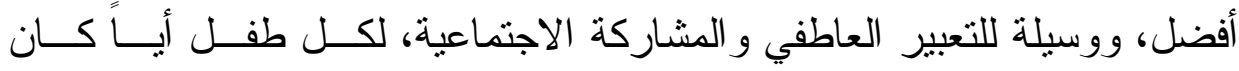
مستوى ذكائه، و المستوى الاجتماعي و الثقافي للبيئة التي نشأ بهـــا (14: 2015 ,

.(Lee and ChuanL

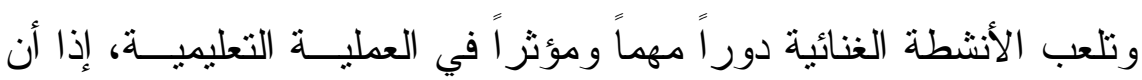

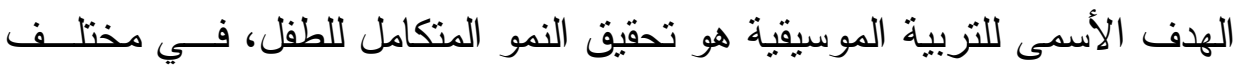
النو احي الجسمية و العقلية و الانفعالية و الاجتماعية و الخلقية، وبالتالي تحقق للطفل

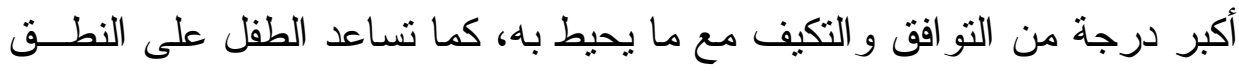

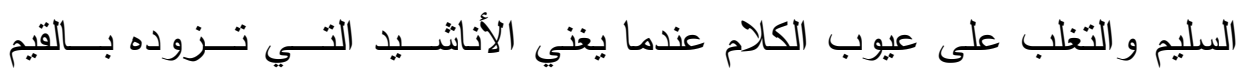

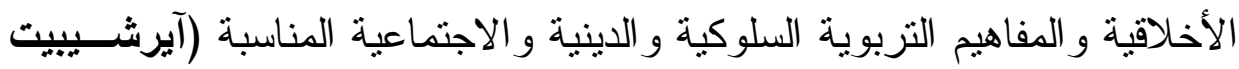

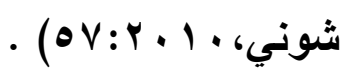

وتعد الأنشطة الموسيقية من أكثر الطرق فاعلية في تتمية كافة جو انب نمو

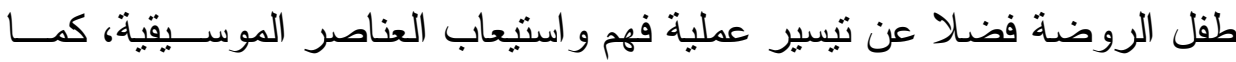

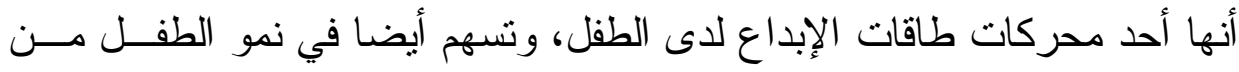

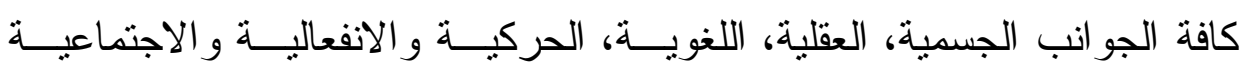

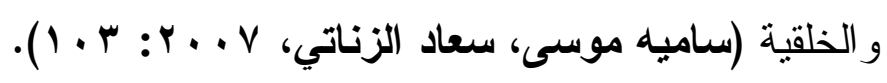

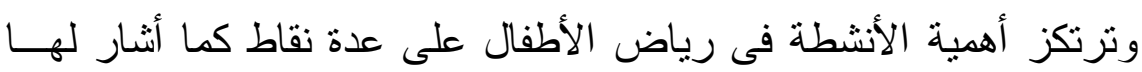
فريق بجامعة ولاية لاوا

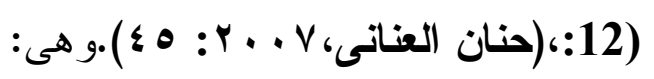

• • تعد إحدى المقومات الأساسية لتحقيق التتمية المر غوبة في شخصية الطفل.

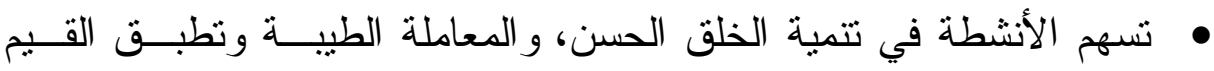

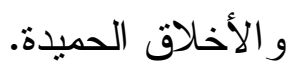


تسهم بترغيب وتحبيب الطفل بالروضة، مما يجعلها أكثر فعالية وتأثير ا في حياته.

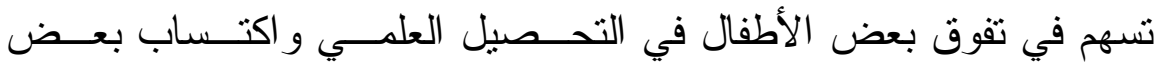
المهار ات في الحياة.

ينمي النشاط في الطفل القدرة على تحمل المسئولية مستقبلا ويكسبه الثقــة بالنفس. و اللغة و الأنشطة الغنائية الموسيقية يرتبط كل مــنهم بـالأخر ، ويلتقيــان

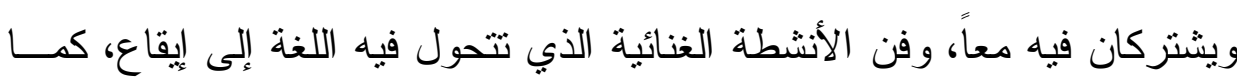

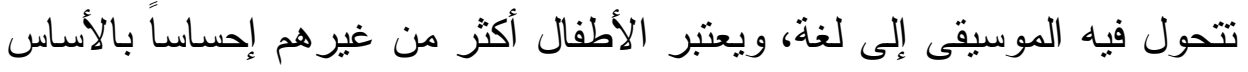

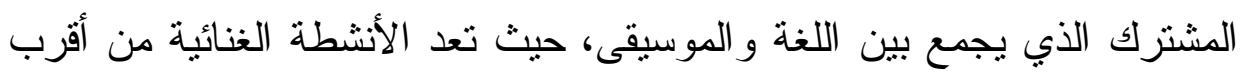

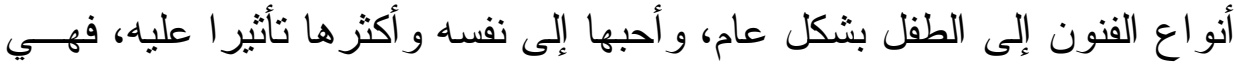

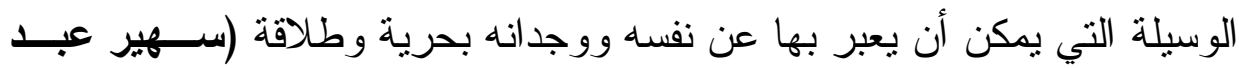

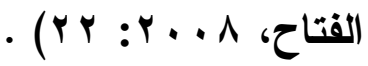
r أهداف الأنشطة (الغنائية :

وتهدف أغنية الطفل في مرحلة الطفولة إلى تحقيق وظيفتين كما أثنار لها

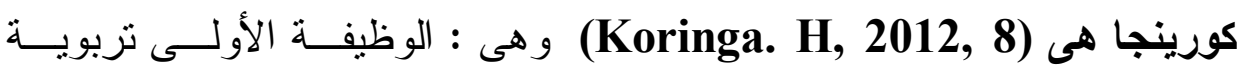
و الوظيفة الثانية فنية، وتعتبر تتمية الوعي الاجتماعي و القومي و الديني و إكسـاب الابس

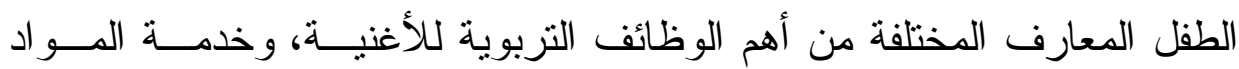

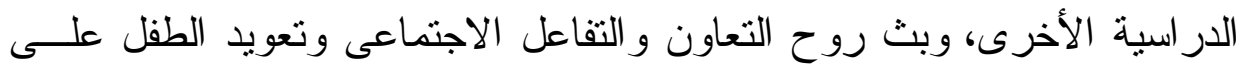
التفكير المنطقي و المنظم وتصريف طاقات الطفل وتعريفه بالعالم الخارجي، كلها

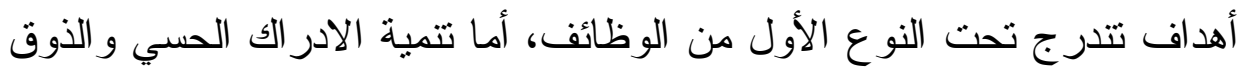


الموسيقي، وتتمية مهار ات السمع وتعريف الطفل بعناصــر الكتابــة الموســيقية

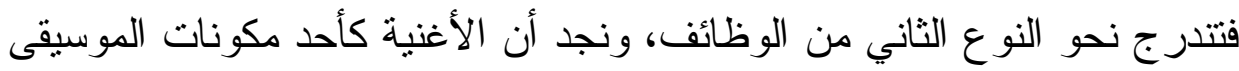

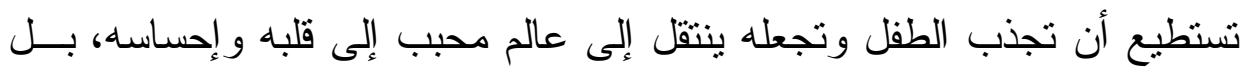

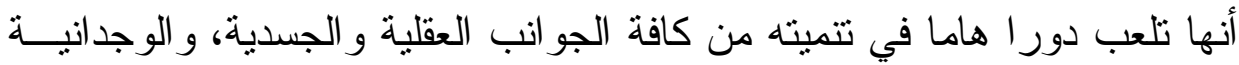

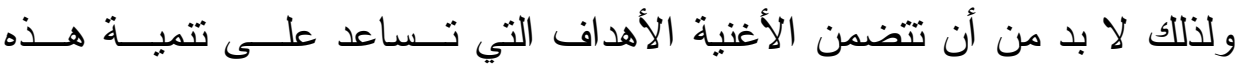

$$
\text { الجو انب. }
$$

ويؤكـــ [Catherine,\& Augustine,2012: 17) ] أن الأنـشطة

الغنائية في مرحلة رياض الأطفال تهدف إلى الأمور التالية :

1- تسعى الأهداف الموسيقية إلى تتمية القدرات الإبداعية للمتعلمين وتطــــير

$$
\text { التفكير الإبداع لايهم. }
$$

r- تشجيع المتعلمين على ابتكار بعض الجمل اللغوية ونطقه بها بشكل سـليم

$$
\text { مما يؤدي ذلك إلى تحسن النطق اللغوي لديه . }
$$

ب- تعمل الأنثطة الموسيقية وما بها من ألحان مختلفة على تمكين المتعلمـين

$$
\text { من الطلاقة في الحديث و الإنصات و الاستماع الفعال. }
$$

ع- تمكين المتعلمين من تتمية الإدر الك الحسي لديهم مما سيؤدي ذلــــ إلـى

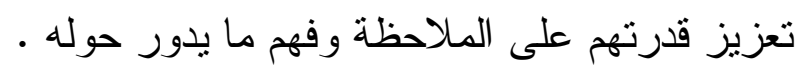

0- تعزيز السلوك الإجتماعي الإيجابي من خــلد تمكـين المتعلمـين مـن

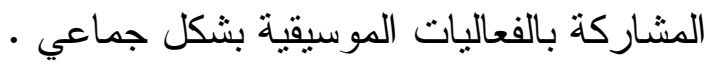

1- تعزيز حس المواطنة و الإنتماء للوطن و الحفاظ على الهوية الوطنية لــدى

$$
\text { المتعلمين من خلال نلك الأنشطة الموسيقي. }
$$




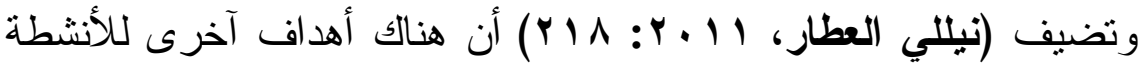

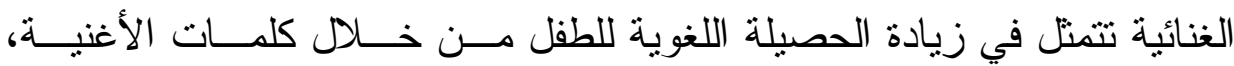
و إكساب الطفل الكثير من المفاهيم التي تساعد على التعـرف علــى المناســبات

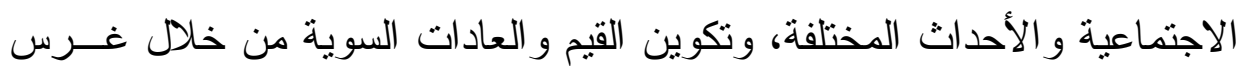

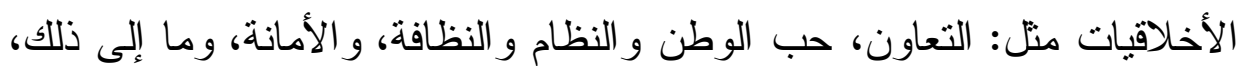
تعويد الطفل على المشاركة الجماعبة و التعاون و الإحساس بدوره، بالإضافة إلى الى

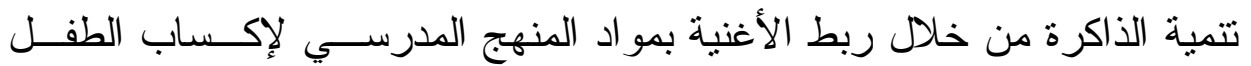
المعارف و المعلومات بطريقة حيوية ومشوقة .

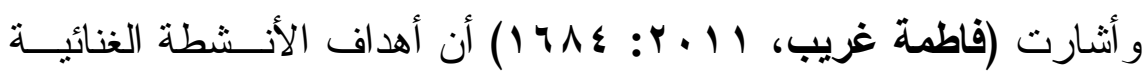
لطفل الروضة تسعى إلى إعلاء نقافة الطفل عن طريق نقل المعلومــات القيهــة من خلال الأغنية، تربية الذوق الفني الجيد لدى الطفل خاصة عندما يكون الأداء

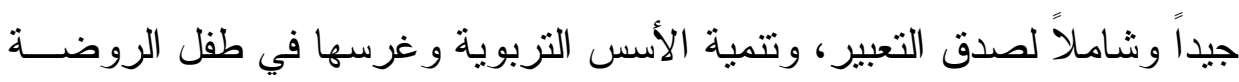

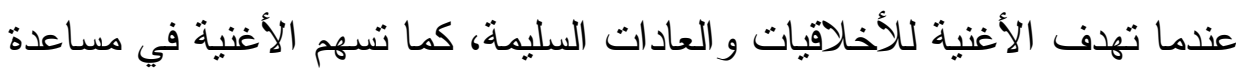

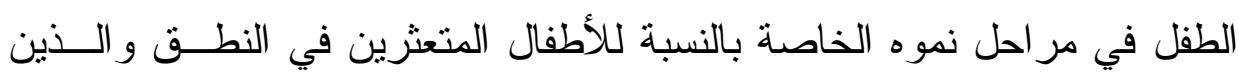

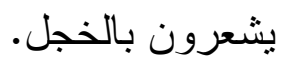
r) مو اصفات النشاط الغنائي لطقل الروضة : هناك عدة اعتبار ات لا بد من مر اعاتها لكي تحقق الأغنية الهـدف الفنـي

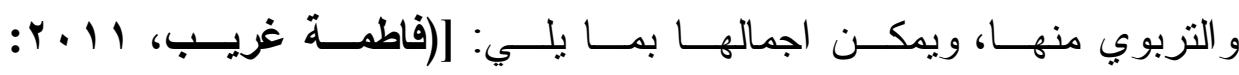
: [(Taylor,et all,2011: 35)،( ( 1 ฯ 
- تعبر عن البيئة المحيطة بالطفل و اهتماماته، ويمكن أن يكتسب من خلالها بعض الدفاهيم العلمية، اللغوية، الاجتماعية. - تكون ذات قيمة تعبيرية، ولها معنى و اضح.

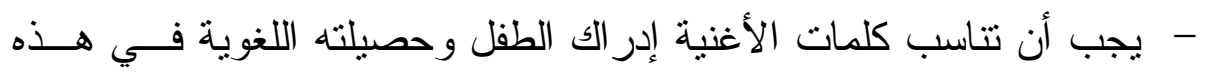

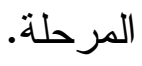
- - أن تكون الكلمات من جمل منوسطة حتى لا تبعث الملل في نفوس الطفل. • ثانياً : اللحن : - يجب أن يعتمد على العبار ات الموسيقية القصيرة. - أن يعتند على التكر ار اللحني ليسهل حفظه. - أن يكون اللحن سلسا قصير ا كثير الخطوات السليمة، بعيدا عن المسسافات الو اسعة.

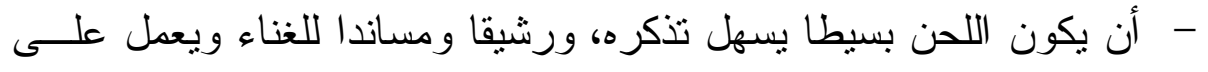

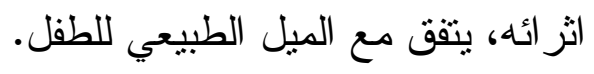
- أن يتكون اللحن من عبار ات موسيقية قصيرة يمكن غنائها في نفس واحد. - ذات إيقاع بسيط و اضح.

وفي ضوء ما سبق تعد الأشطة الغنائية من أهم الأشطة المعبرة عـن

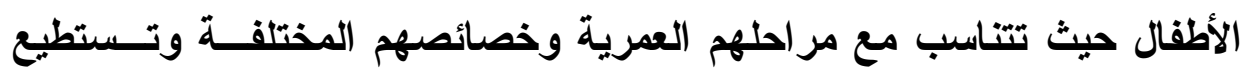

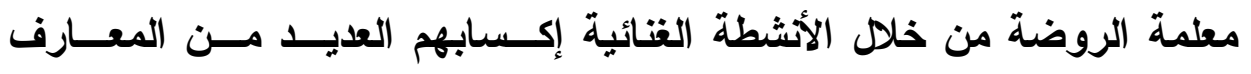

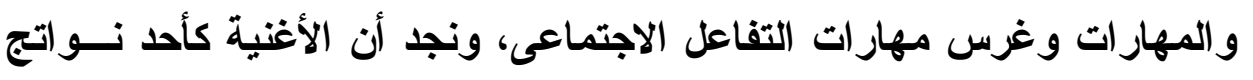


الموسيقى تستطيع أن تجذب الطقل وتجعله ينتقل إلى عالم محبب إلــى قلبــه

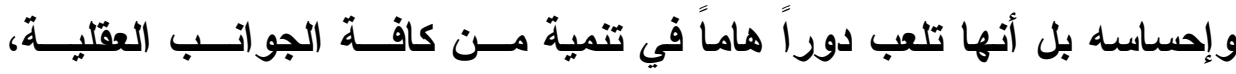
و الجسدية و الوجدانية.

؛) دور الأشطة الغنائية في تنمية التفاعل الاجتماعى لطقل الروضة :

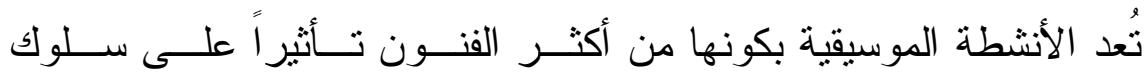
الإنسان بوجه عام، و الطفل بوجه خاص، فهي تمنل جز ء من ثقافته، وتعزز لديه

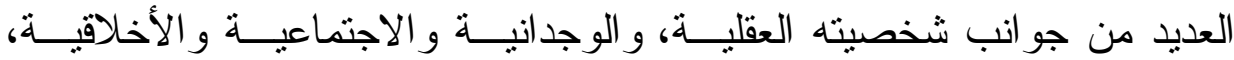
فتر اها تسهم في صقل مشاعره، لتسمو بروحه ووجدانه، فالموسيقى أداة تربويـــة

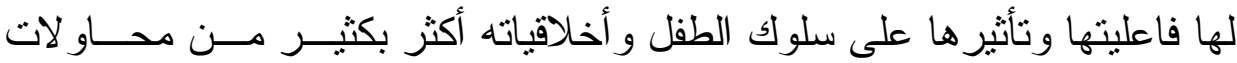
إقناعه بالقول و الإرشاد فهي تسهم في تحرير مشاعره من كل مـــا هــو ســلبي،

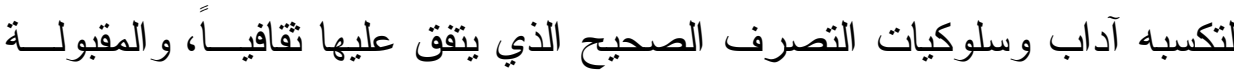

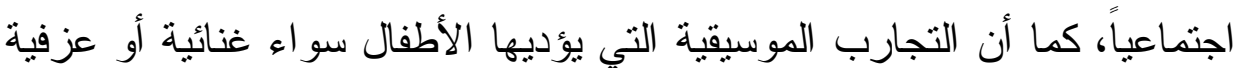
أو حركية جميعها يسهم ليس فقط في تحسين المفاهيم الموسيقية بل تسهم أيـضاً في غرس العديد من المبادئ و القو اعد و السلوكيات الحسنة المتفق عليها اجتماعياً

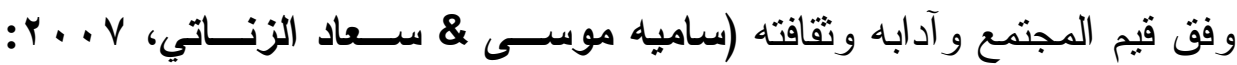

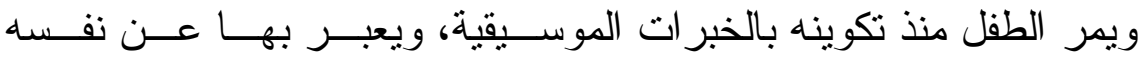
وجاء التزبويون الموسيقيون ليجعلو ا من هذه الخبر ات الموســيقية وسـيلة مــن بــن

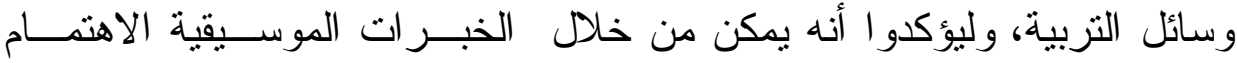

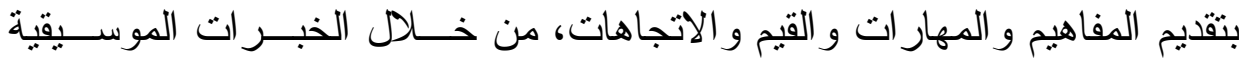

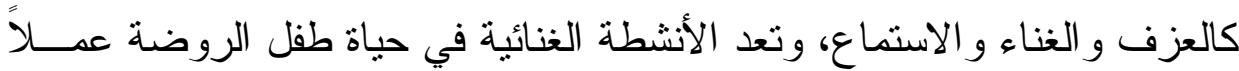




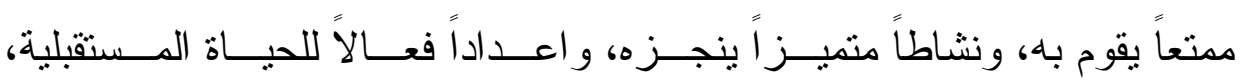

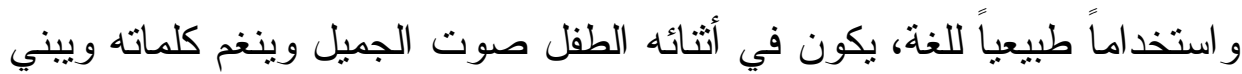

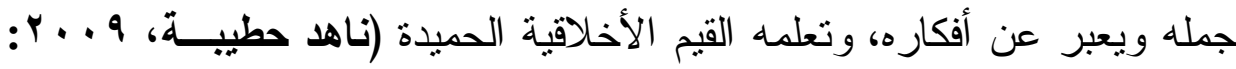

كما أن الأنشطة الغنائية بالنسبة لطفل الروضة تعني له الحياة واستكثاف الذات و البيئة المادية و الاجتماعية المحيطة به و التي تعطيه الـسرور و الحريــة

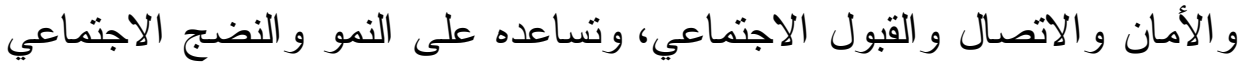

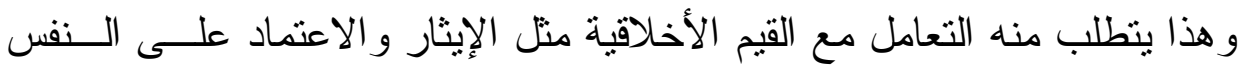
و التعاون و التفاعل الاجتماعى وغير ها من القيم، وهي تعتبر أولى بذور النجـــــاح

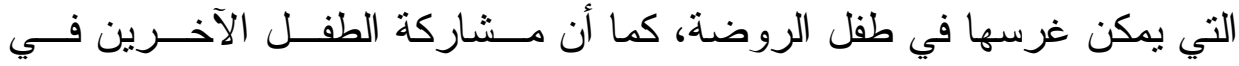

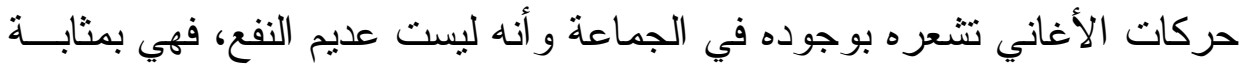

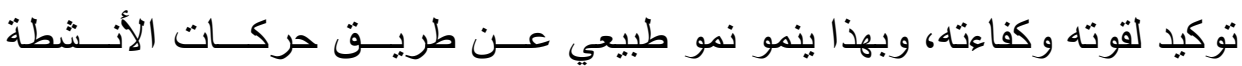

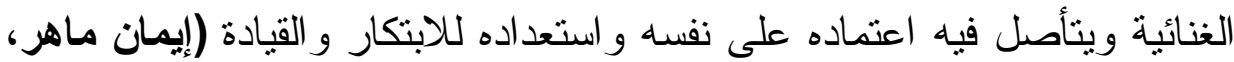

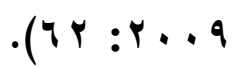

وتُعد الثربية الموسيقية و الموسيقى من الأنشطة التي يمكن أن تدخل المرح و السرور على نفوس الأطفال في هذه المرحلة، إلى جانب دورها التربوي الفعال في مساعدة الطفل على النمو المتكامل في جميع جو انب شخصيته، وعن طريق الأنشطة الموسيقية يمكن مساعدة الطفل على تتمية حو اسه، كما يمكن من خلالها تعلم اللغة، وهي تساعد كذللك على تتمية القيم الاجتماعية من خلال المشاركة في الأنشطة الموسيقية و التعاون مع الآخرين و آداب الحوار، وفي التعبير عن ذاتــهـ

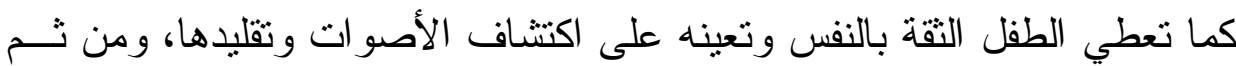


فإن الموسيقى تسهم في تتمية الابتكار لديه وتتمية التفاعل الاجتمــــى (محمـــ كمال \& نفين عرنوس، 9 . . ץ: ؛ ب).

وفي أثناء ممارسة الطفل للأنشطة الغنائية الحركيــة ينــدمج فــي أدوار

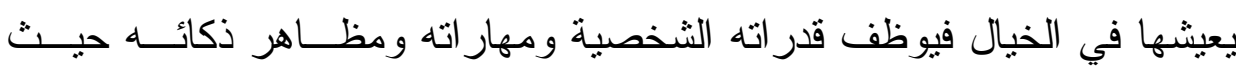
يلاحظ وينتبه ويبتكر، أغاني الأطفال تمنل فر عاً من التربية الموســيقية عنــدما

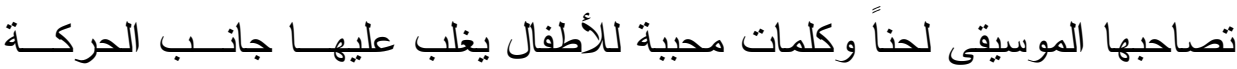
و التمثيل، مما يحث على النشاط وجذب انتباه الطفل مما يجعله أكتــر مــشاركة

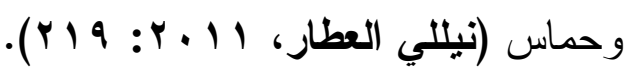

ونستخلص مما سبق أن الأنشطة الغنائية هي مواقف تربويــة يمـــارس

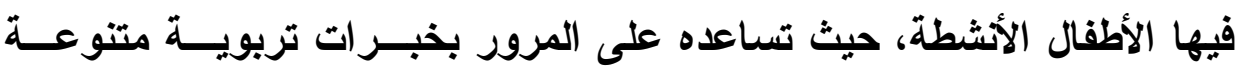
تهدف لتحقيق النمو الشامل المتكامل وفي بناء الشخصية السوية المتكاملة في جميع جوانبه الجسمية والنفسية والعقلية والاجتماعية والأخلاقية، فالأحسشة الموسيقية لايها تأثير خاص على شخصية طقل الروضة لما تحققه من نتــائج ينعكس عليه باكتسابه السلوكيات المرغـوب و إخراجـهـه مــن حالــة التــوتر و التخلص من السلوكات غير المرغوب بها والتي تتعارض مـــع قـيم وثثقافــة

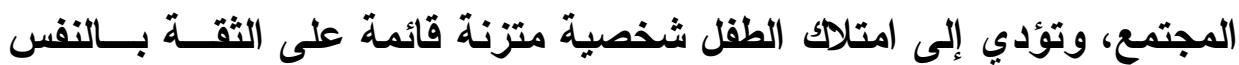
والاستقلاليه والتعاون والابتعاد عن الأنانية وتتمية التعاون وما إلى ذلك مسن مشاعر تعمل على إغناء إحساس الطقل وشعوره بإنسـاتيته وتــــعيم الثثـــة بالنفس وتعبيره عن احساسه دون خجل وزيادة التفاعل بين لطفـلـ وزملاهـــهـ

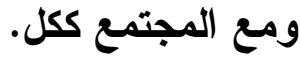


كما أن للأنثطة الغنائية دوراً لا يمكن إغفاله في الثأثثر علـى مهــارات

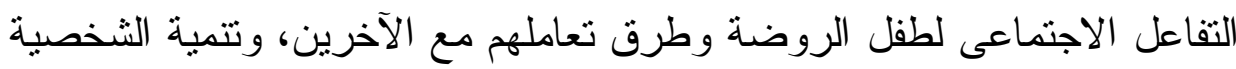

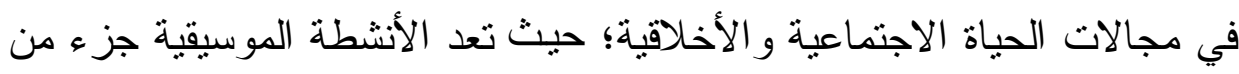

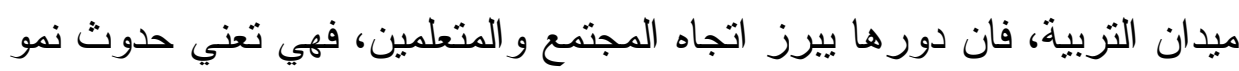

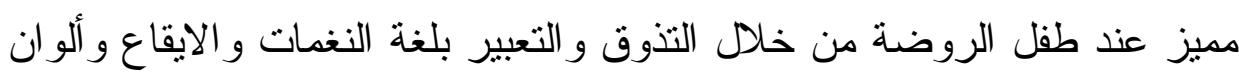
التعبير المختلفة التي تتعكس على شخصيته، و التي تتضح لايه الرؤية الفنية التي

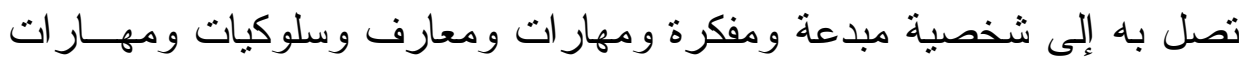

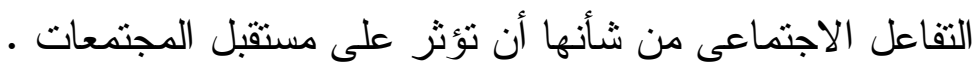
المحور الثانى : التفاعل الاجتماعى :

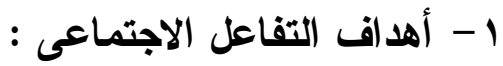

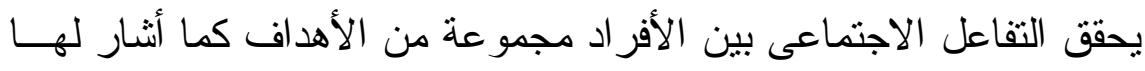

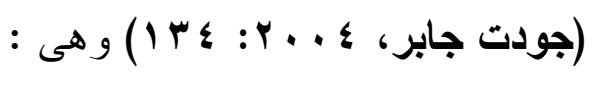

V- ييسر التفاعل الاجتماعى تحقيق أهداف الجماعة ويحدد طرائـق إثـــباع

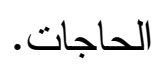

^- يتعلم الفرد و الجماعة بو اسطة أنماط السلوط المتتوعة و الاتجاهـات التهى تتظم العلاقات بين أفراد وجماعات المجتمع فى إطار القيم السائدة و الثقافة و التقاليد الاجتماعية المتعارف عليها. 9- يساعد على تقييم الذات و الآخرين بصورة مستمرة . • 1- يساعد التفاعل على تحقيق الذات ويخفف وطأة الثعور بالضيق، فكثيراً

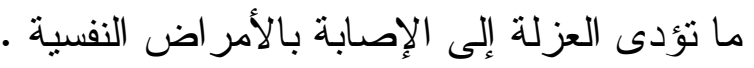




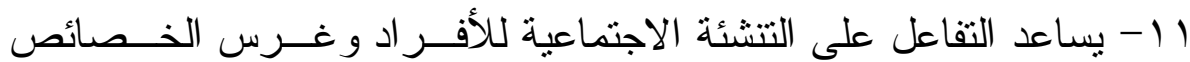
المشتركة بينهم . الماعد

\section{ب - أسس التفاعل الاجتماعى :}

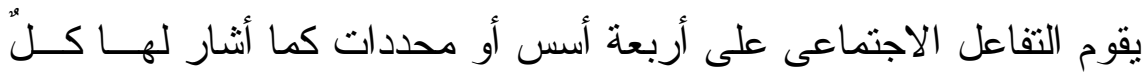

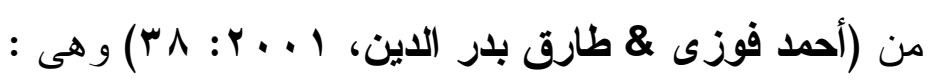

أ- الإتصال : لا يمكن بطبيعة الحال أن يكون هنالك تفاعل بين فــردين دون

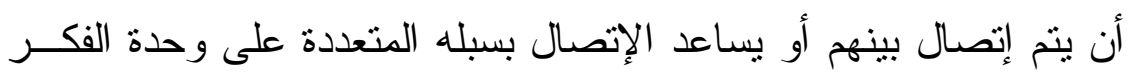

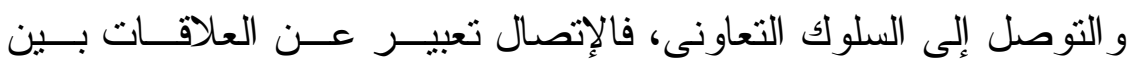
الأفر اد، ويعنى نقل فكرة معينة أو معنى محدد فى ذهن شخص الإنى ما إلـى

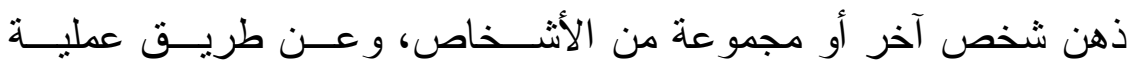
الإتصال بحدث التفاعل بين الأفر اد، وعملية الإتصال لا بمكن أن تحدث أو تتحقق لذاتها، ولكنها تحدث من حيث هـى أســاس عمليــة التفاعـلـل الإنسل الاجتماعى؛ حيث يستحيل فهم ودر اسة عملية التفاعل فى أى جماعة دون

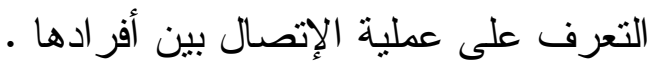

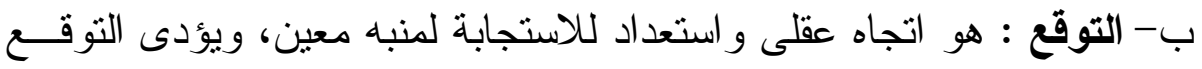

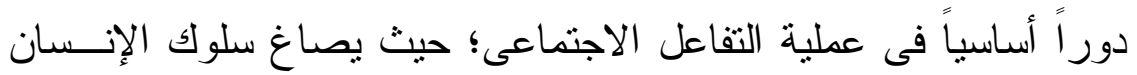

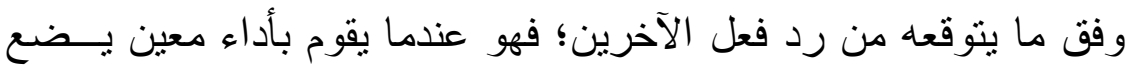
فى اعتباره عدة نوقعات لاستجابات الآخرين كالرفض أو القبول و الثو اب التاب

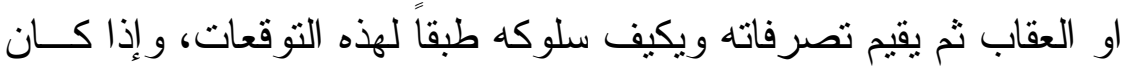

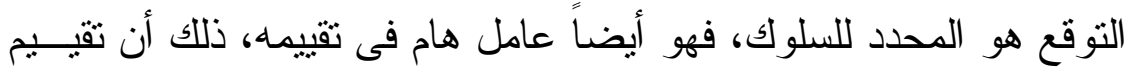

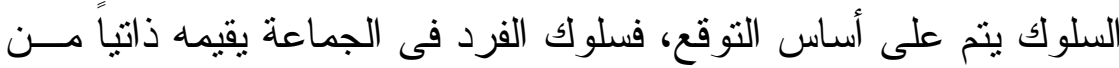


خلال ما يتوقعه عن طريق استقبال الزملاء له، سواء أكان هذا الـسلوك حركياً أم اجتماعياً. .

ويُينى النوقع على الخبرات السابقة أو على القياس بالنسبة إلى أحداث

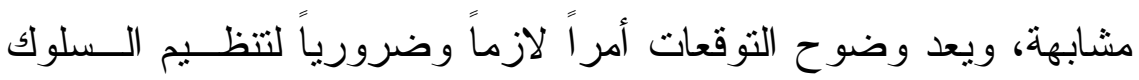

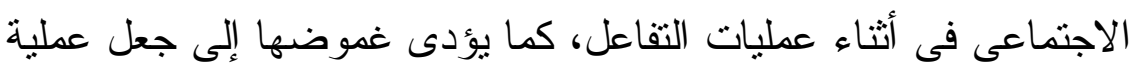

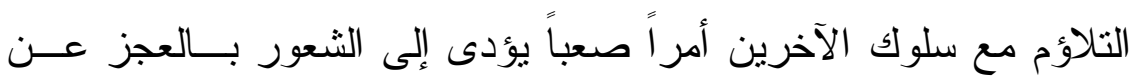

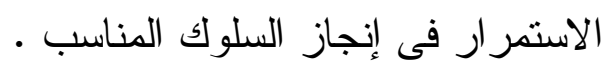

ج- درالك الدور وتمثيله : لكل إنسان دور يقوم به، وهذا الدور يفـسر مسن

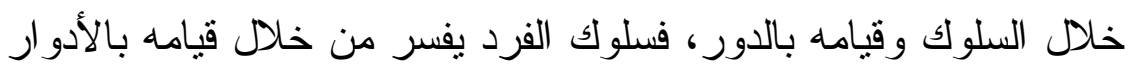

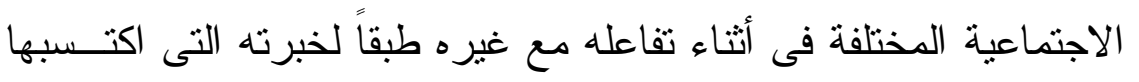

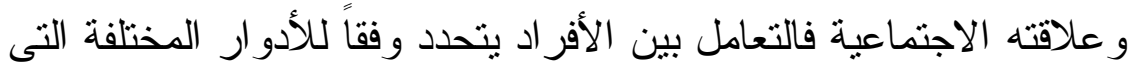
يقومون بها .

ولما كانت مو اقف التفاعل الاجتماعى التى يلعب الفــرد فيهـــا أدواراً

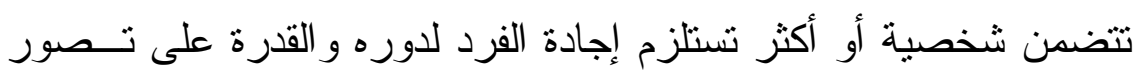

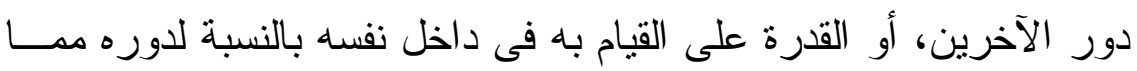

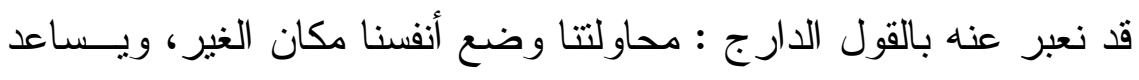

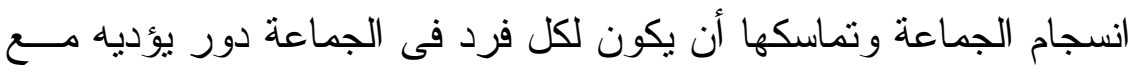

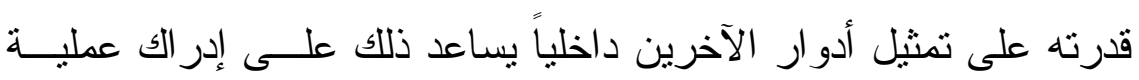

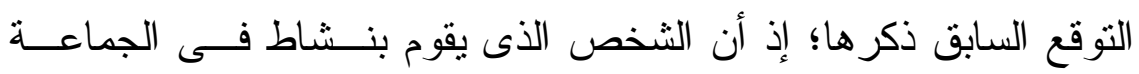
ويعجز عن نوقع أفعال الآخرين لعجزه عن إدر الك أدوارهم و وعلاقة دوره

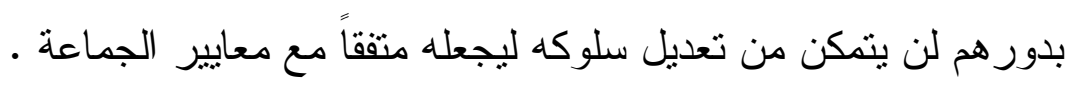


r-دور المعلمة في تنمية التفاعل الاجتمــاعى لطفـل الروضــة باسـتخدام

الأنثطة الغنائية :

تلعب معلمة الروضة دورًا هامًا فى تتمية مهار ات التفاعل الاجتماع لطفل

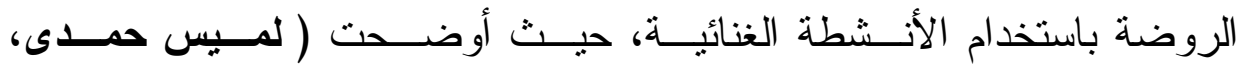

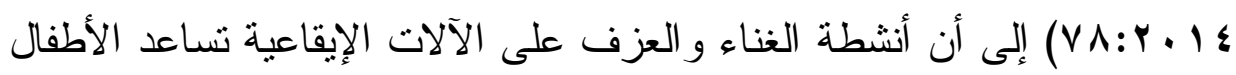

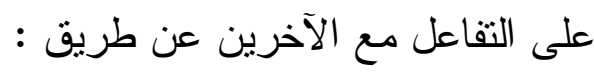
1- نوفير جهاز تسجيل وسماعات الر أس وقصصيًا مسجلة و أنانشيد و أثنــعار ،

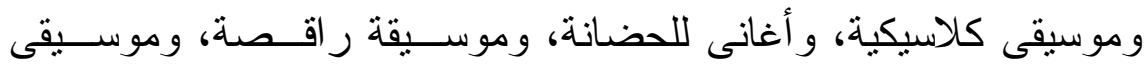

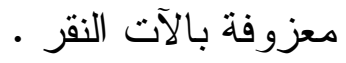
r- استخدام أساليب و أنشطة حسية تعتمد على الإثار ات و الإيقاعات الصوتية r- تشجيع الطفل على الإنشاد و الغناء . ع- توفير فرصًا كبيرة للأطفال للاستماع بالألحان و الاندماج فيها .

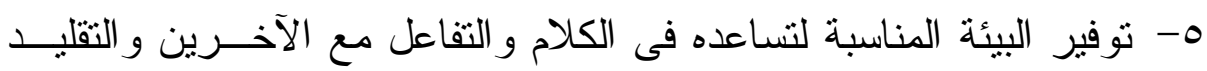

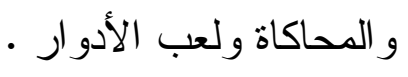

1- تتمية مهارة حفظ الأغانى التعليمية وترديدها مع أقر انه وتمثيلها وتـشجيع الطفل على القر اءة و الكلام و النطق. V تتمية مهارة استيعاب التعليمات وتتفيذ الأوامر الموجهة للطفل .

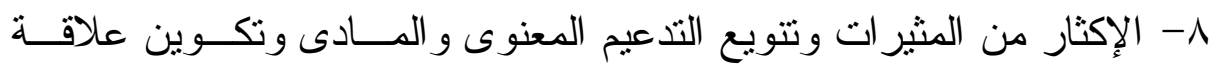
إيجابية مع الطفل. 9- زيادة مستوى الطموح و التتافس و التعاون • 
للإجابة عن أسئلة البحث و التحقق من صحة الفروض تم إتباع الإجر اءات

•ـ أولاً: إعداد قائمة بمهارات التفاعل الاجتماعى المناسب تنميتها لاى طفــلـ

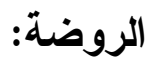

$$
\text { للإجابة على السؤ ال الأول من أسئلة البحث وهو : }
$$

ما مهار ات التفاعل الاجتماعي الفرعية المناسب تنميتها لاى طقل الروضة؟

$$
\text { تم إعداد القائمة وفقاً للإجر اءات التالية : }
$$$$
\text { 1- تحديد الهدف من إعداد القائمة . }
$$$$
\text { r- إعداد الصورة الأولية للقائمة . }
$$

r- تطبيق استبانة مهار ات التقاعل الاجتماعى على مجموعة مـن معلمــات

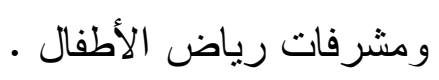

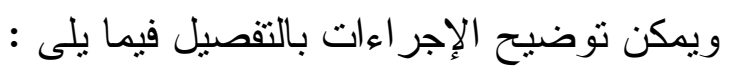

$$
\text { ( ) تحديد الهاف من إعداد القائمة : }
$$

تهدف القائمة إلى تحديد مهارات التفاعل الاجتماعى المناسب تتميتها لدى

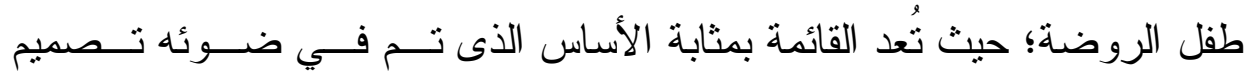

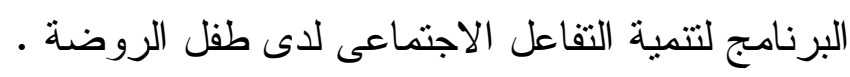
r) إعداد الصورة الأولية للقائمة : تم إعداد الصورة الأولية للقائمة من خلال :

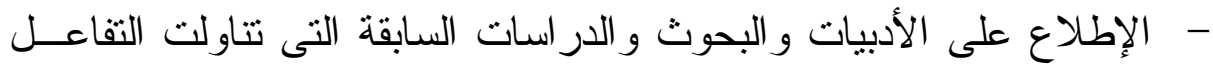

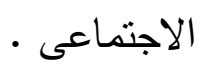


- خصائص طفل الروضة .

وون خلال ما سبق تم إعداد الصورة الأولية لقائمـــة بمهــار ات التفاعـلـ

الاجتماعى المناسب تتميتها لدى طفل الروضة، وقد اثتنملت الــصورة الأوليــة

للقائمة على خمسة مهار ات يندرج تحت كل مهارة مجموعــة مــن العبــار ات الفرعية؛ كما يتضح من الجدول التالى :

جدول (1) مهارات التفاعل الاجتماعى

\begin{tabular}{|c|c|c|c|}
\hline |الوزن النسبي لكل بعد رئيسة \% & عدد العبارات الفرعية لكل بعد & المهارات الفرعية & b \\
\hline$r_{1}, \Sigma T$ & 9 & التعاون & 1 \\
\hline $17,7 V$ & v & التو اصل & $r$ \\
\hline$r,, \varepsilon r$ & 9 & حب الآخرين & $r$ \\
\hline $19, .0$ & $\wedge$ & المشاركة & $\varepsilon$ \\
\hline Y), $\{r$ & 9 & آداب الحوار & $\bullet$ \\
\hline $1 \ldots$ & $\varepsilon r$ & المجموع & \\
\hline
\end{tabular}

تم تضمين القائمة فى صورتها الأولية فى صــورة اســتبانة '*؛ و التـى

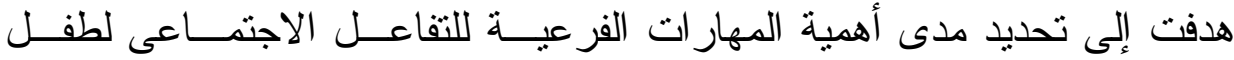
الروضة من خلال مقياس متدرج (هام بدرجة كبيرة، هام بدرجة متوسطة، غير

وقد تم عرضها فى صورتها الأولية على مجموعة من المحكمـين مسـن

السادة أعضاء هيئة التدريس المختصين في مجال مناهج وطرق تعليم الطفل وقد أسفرت أر اء المحكمين عن:

1 ("*) ملحق (1) : استبانة مهارات التفاعل الاجتماعى المناسب تنميتها لاى طقل الروضة . 
- مناسبة استبانة مهار ات التفاعل الاجتماعي وما تضمنته مـن مهـار ات

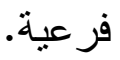

- - إعادة ترتيب بعض المهار ات الفر عية لتتفق وطبيعة اداء المهارة. - تعديل صيغة بعض المهار ات الفرعية لتصبح أكثر وضوحا. ؛) تطبيق استبانة مهارات التفاعل الاجتماعى :

تم تطبيق استبانة مهارات التفاعل الاجتـــــ؛ لحــصر آراء دعلمــات

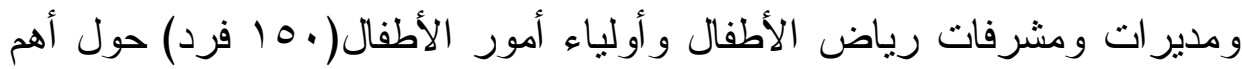

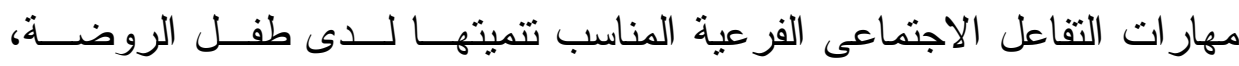
و الجدول النالى يوضح ذلك:

جدول (r)

آراء العينة حول مهارات التفاعل الاجتماعى المناسب تنميتها

\begin{tabular}{|c|c|c|c|c|c|c|c|c|c|}
\hline \multirow{2}{*}{\multicolumn{2}{|c|}{ غير هام }} & \multicolumn{4}{|c|}{ الاستجابات } & \multirow{2}{*}{\multicolumn{2}{|c|}{ هام بلرجة كبيرة }} & \multirow{3}{*}{ الفرعية } & \multirow{3}{*}{ p } \\
\hline & & \multicolumn{2}{|c|}{ هام بدرجة ضعيفة } & \multicolumn{2}{|c|}{ هام بدرجة متوسطة } & & & & \\
\hline$\%$ & ك & $\%$ & ك & $\%$ & ك & $\%$ & كs & & \\
\hline . & . & T,TV & $\varepsilon$ & r & 0 & $9 \varepsilon$ & $1 \leqslant 1$ & التعاون & 1 \\
\hline 9. & 1ro & $\varepsilon$ & 7 & T,TV & $\varepsilon$ & ( & 0 & التواصل & r \\
\hline ט & $\wedge$ & Tr & r & $7,7 V$ & 1. & $\wedge \neg, \uparrow \vee$ & $1 \pi$. & حب الآخرين & $r$ \\
\hline AV, Tr & וT & Y,Y T & $\varepsilon$ & r Tr, & 0 & $7,7 V$ & 1. & المشاركة & $\varepsilon$ \\
\hline $7,7 \mathrm{~V}$ & 1. & $1 \cdot$ & 10 & $7,7 V$ & 1. & $V 7,7 V$ & 110 & آداب الحوار & 0 \\
\hline
\end{tabular}

من البيانات الو اردة فى الجدول السابق و الخاص باستجابات أفر اد العينة،

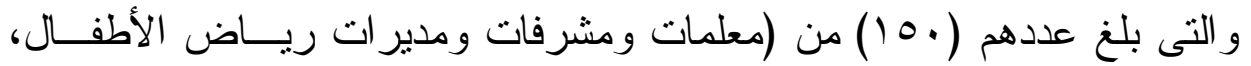


وأولياء أمور أطفال الروضة) حول مهــار ات التفاعـلـل الاجتمــــى الفرعيــة المناسب تتميتها لدى طفل الروضة يتضح الآتى :

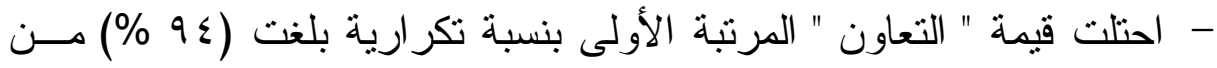

$$
\text { حيث درجة الأهمية " بدرجة كبيرة " . }
$$

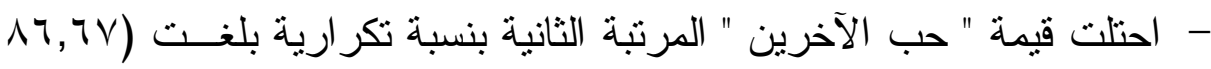

$$
\text { \% من حيث درجة الأهمية " بدرجة كبيرة " . }
$$

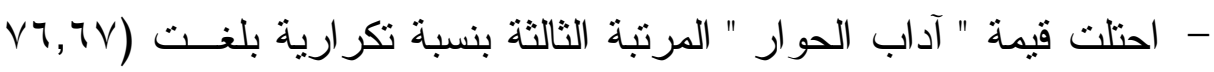

$$
\text { \%) من حيث درجة الأهمية " بدرجة كبيرة " . }
$$

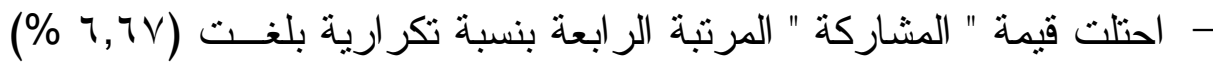

$$
\text { من حيث درجة الأهمية " بدرجة كبيرة " . }
$$

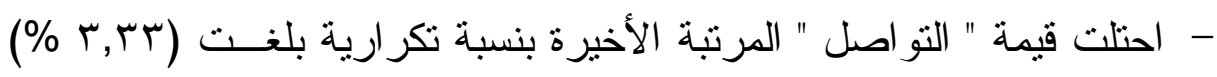

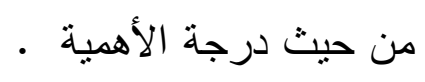

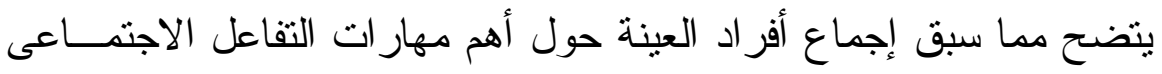

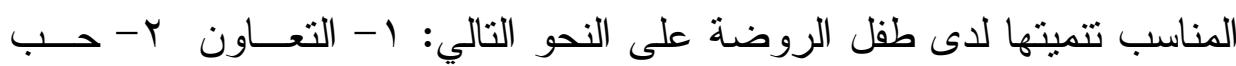

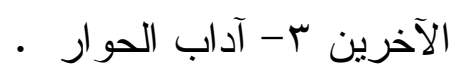

و هذه الههار ات الفرعية الثلاثة للتفاعل الاجتماعى هى التى تم تتميتها مسن

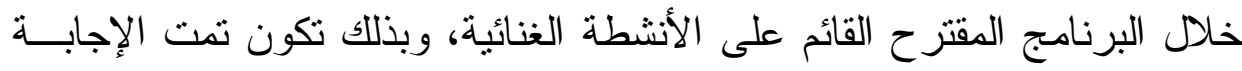

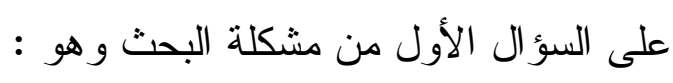

" ما مهارات التفاعل الاجتماعى المناسب تنميتها لاى طقل الروضة ؟ " 
• ثانياً : إعداد برنامج مقترح قائم على الأنشطة الغنائية :

للإجابة على السؤ ال الثانى من أسئلة البحث وهو :

"ما البرنامج المقترح القائم على الأكسشطة الغنائيــة الــــى ينـــى التفاعـل

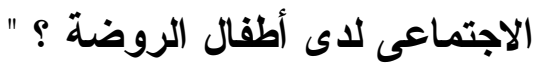

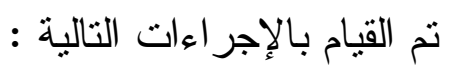

( ) تحديد أسس إعداد البرنامج المقترح :

تم إعداد البرنامج المقترح فى ضو اء الأسس التالية :

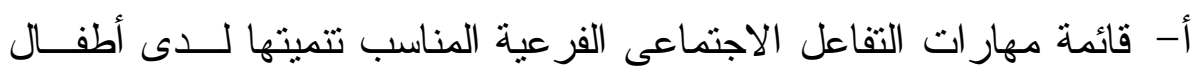

$$
\text { الروضة. }
$$

ب- و اقعية البرنامج من حيث منطلبات تنفيذه؛ حيث روعي عند إعـداده أن

تكون متطلبات تتفيذه و اقعية وممكنة من حيث الزمن و الإمكانات متاحسة

$$
\text { لتنفيذه . }
$$

ج-مر اعاة المرونة الكافية عند إعداد البرنامج المقترح بإدخــال التعـديلات

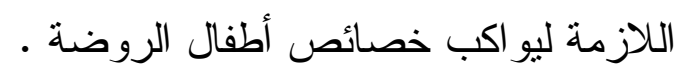

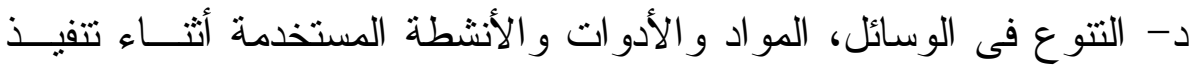

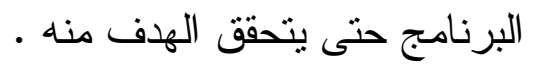

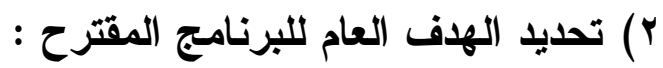

تم تحديد الهدف الرئيسى للبرنامج المقترح وهو تتمية مهــار ات التفاعـل

الاجتماعى لدى أطفال الروضة من خلال الأنشطة الغنائية . 
r) تحديد الأهداف الخاصة للبرنامج المقترح :

يتقر ع من الهدف العام للبرنامج ثلاثة من أهداف خاصة وهى :

- - تتمية مهارة التعاون لدى طفل الروضة .

- تمية مهارة حب الآخرين لدى طفل الروضة .

- ت تمية مهارة آداب الحوار للدى طفل الروضة .

ع) محتوى البرنامج المقترح :

تم تحديد محتوى البرنامج المقتر ح فى صورة أنثطة غنائيــة بالاســتعانة

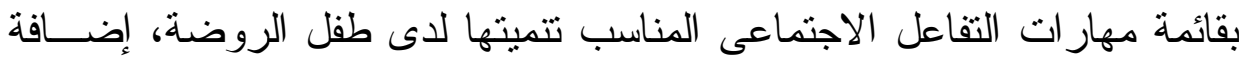

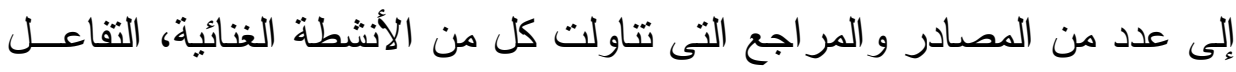

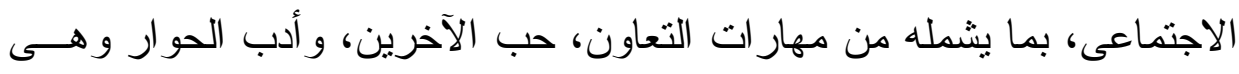

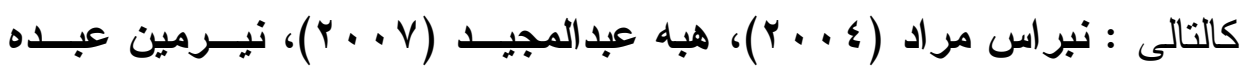
$\cdot(r \cdot 1 \cdot)$

وقد روعى عند اختبار المحتوى ما يلى :

أـ أن يرتبط المحتوى بالأهداف الخاصة للبرنامج المقتر ح الدحددة سابقاً .

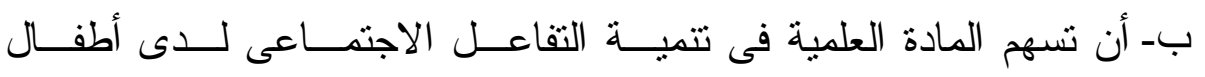

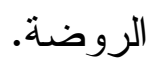

ج- أن تتعدد مستويات المحتوى وفقاً للفروق الفردية بين أطفال الروضة . . دـ أن تكون المادة العلمية ذات تشلسل منطقى ومنظم . هـ أن يتضمن أنثطة وتدريبات متتوعة . 


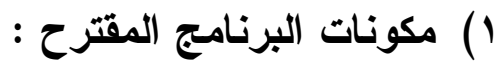

أ- أ- مقدمة

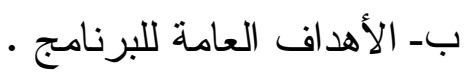

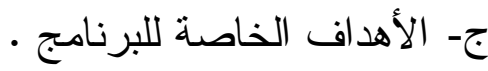

د- الأدو ات و الوسائل المستخدمة فى تتفيذ البرنامج •

ه- الأنشطة المستخدمة فى تتفيذ البرنامج •

و - الخطة الزمنية لتنفيذ الأنشطة .

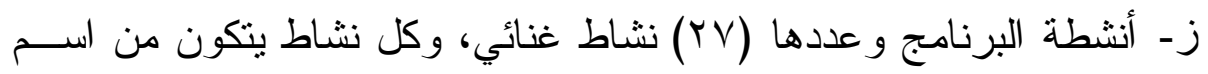

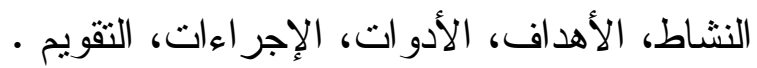

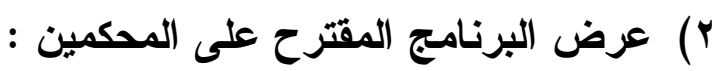

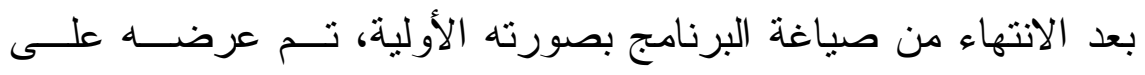

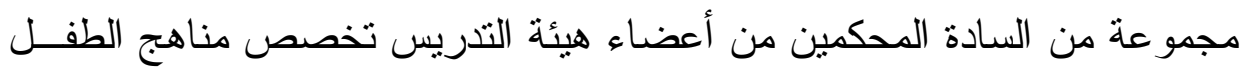

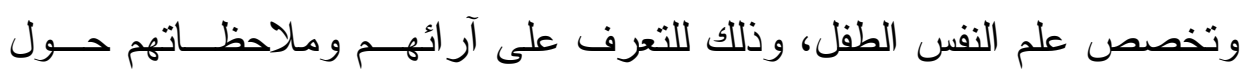

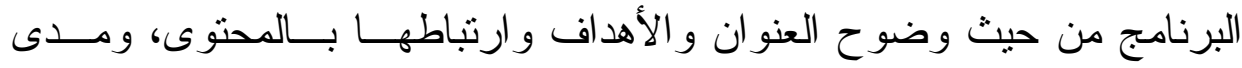
مناسبة المحتوى وصحة مادته العلمية و اللغويــة وطريقــة عرضــــهـ و الوســائل

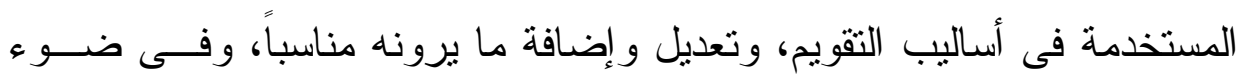

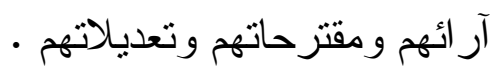




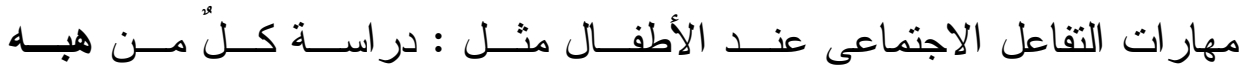

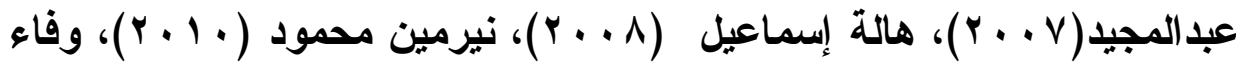

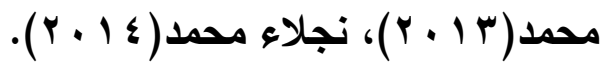

وقد تم بناء مقياس مهار ات التفاعل الاجتماعى فى ضــــــ أهـــم ثــلاث مهار ات للتفاعل الاجتماعى، وروعى عند صياغة أسئلة المقياس المــصور مـــا : يلى : أ- أن نكون الصورة و اضحة . ب-أن تكون اللغة المستخدمة مناسبة لطفل الروضة . ج-أن تتتاسب الأسئلة مع أهداف المقياس • وتم بناء المقياس طبقا لطريقة ليكرت لكونه يتميز بالسهولة النـسبية فـى التصميم و التطبيق و التصحيح، بالإضافة إلى أنه شامل ومناسب ودقيق، وبالتالى أكثر ثباتاً .

وقد تم صياغة (YV) سؤالاً ، كل سؤال أسفله ثناث صور إحداها إيجابية للمهارة، وصورة محايدة، و الثالثة صورة سلبية؛ كما فى الجدول التالى : جدول (r) عدد الأسئلة فى مقياس التفاعل الاجتماعى

\begin{tabular}{|c|c|c|c|}
\hline الوزن النسبى لكل مهارة & عدد الأسئلة لكل مهارة & المهار ات الرئيسة للتفاعل الاجتماعى & م \\
\hline זr, זr & 9 & التعاون & 1 \\
\hline س & 9 & حب الآخرين & r \\
\hline 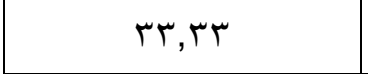 & 9 & آداب الحوار & $r$ \\
\hline$\% 1 \ldots$ & rV سؤالاً & المجموع الكلى & \\
\hline
\end{tabular}


تم تصحيح عبار ات مقياس التفاعل الاجتماعى المصور، طبـــاً لطريقــة

$$
\text { ليكرت؛ وفقاً للجدول التالى : }
$$

جدول (ء) طريقة تسجيل الارجات لكل عبارة من عبارات المقياس

\begin{tabular}{|c|c|c|c|}
\hline سلبية & محايدة & إيجابية & توزيع الدرجات \\
\hline 1 & r & r & الموجبة \\
\hline r & r & 1 & السالبة \\
\hline
\end{tabular}

فى ضوء الجدول السابق يعطى الطفل (r) درجة فى حالة وضع علامـــة ( ل) أسفل الصورة الإيجابية (مو افق)، يعطى الطفل (Y) درجة فى حالة وضــع علامة ( ل) أسفل الصورة المحايدة (غير متأكد)، يعطى الطفل درجة و احدة فى

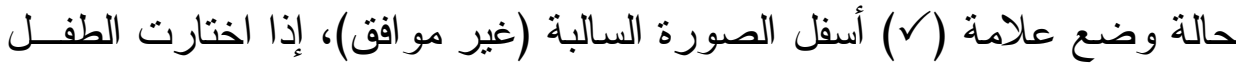
الصورة السلبية (ج) توضع تحتها علامة (ل) ويعطى الطفل س درجات لأنهـا

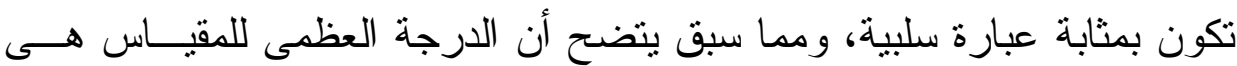

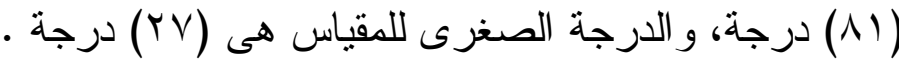

$$
\begin{aligned}
& \text { ؛) التحقق من صدق المقياس ( صدق المحكمين ) : }
\end{aligned}
$$

تم عرض مقياس التفاعل الاجتماعى المصور بــصورته الأوليــة علــى مجموعة من السادة المحكمين و الخبر اء المتخصصين من أعضاء هيئة التدريس المتخصصين في مناهج الطفل و المتخصصين في علم الــنفس الطفـلـ بغــرض

$$
\text { التعرف على آر ائهم من حيث : }
$$




$$
\text { أـ د مدى وضوح عبار ات المقياس • }
$$

ب- مدى انتماء وقياس مهارات مقياس التفاعل الاجتماعى الفرعية لكل مهارة رئيسة متضمنة بالمقياس •

$$
\text { ج- سلامة الصياغة اللغوية لعبار ات المقياس . }
$$

وقد أجمع أغلب السادة المحكمين على مناسبة المقياس لطفل الروضة .

$$
\text { •) التجربة الاستطلاعية للمقياس : }
$$

تم تطبيق مقيــاس التفاعـلـل الاجتــــاعى المــصور علــى المجموعــة

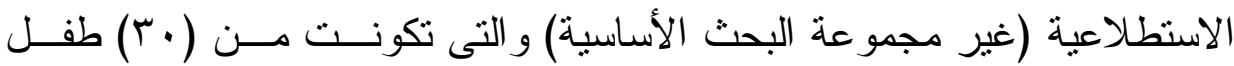
وطفلة بروضة سنابل؛ وذلك بهدف :

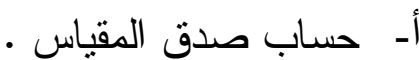

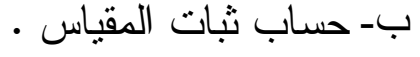

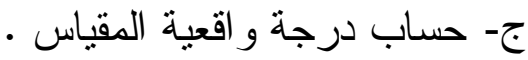
د- حساب زمن الإجابة عن المقياس • وفيما يلى تتاول ذلك بالتفصيل : أ- حساب الصدق " التجانس الاخلى " : بالئ

تم حساب صدق الاتساق الداخلى لمقياس التفاعل الاجتـــاعى المـصور،

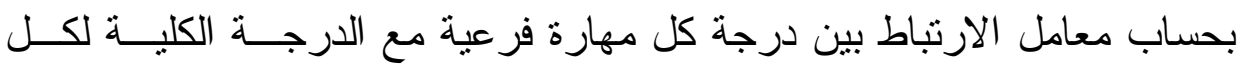
مهارة رئيسة؛ وذلك كما يوضحه جدول (0) : 
جدول (0) معاملات الارتباط بين درجة كل مهارة فرعية من أسئلة

المقياس مع الدرجة الكلية لكل مهارة رئيسة

\begin{tabular}{|c|c|c|c|c|c|c|}
\hline 0 & $\varepsilon$ & $r$ & r & 1 & المفردة & \\
\hline \multirow[t]{3}{*}{$*,, \varepsilon \cdot r$} & $*,, \Sigma) \mu$ & $*, \varepsilon \mid \mu$ & *, rVY & $* *, v \mid r$ & معامل الارتباط & \\
\hline & 9 & $\wedge$ & V & 7 & المفردة & التعاون \\
\hline & $* *$, oV 1 & $* *, \vee \vee>0$ & $* *, V \cdot r$ & $* *, \vee \vee \neg \leq$ & معامل الارتباط & \\
\hline $1 \leq$ & ir & Ir & 11 & 1. & المفردة & \\
\hline \multirow[t]{3}{*}{$* *, V T r$} & $* *, \wedge r T$ & $* *, \vee \backslash \backslash 7$ & $* *, \vee \backslash \backslash 7$ & 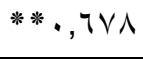 & معامل الارنباط & حب الآخرين \\
\hline & 11 & iv & 17 & 10 & المفردة & \\
\hline & $* *, 9 \leq 0$ & $* *, 9 r r$ & $* *, 9 \mu \wedge$ & $*,, \varepsilon \cdot r$ & معامل الارتباط & \\
\hline$r r$ & Yr & YI & $r \cdot$ & 19 & المفردة & \\
\hline \multirow[t]{3}{*}{$* * .07 \mathrm{~V}$} & $* * ., 01 T$ & $*,, \Sigma \leqslant r$ & $*,, \varepsilon \ldots$ & $*, r Y \leq$ & معامل الارنباط & آداب الحوار \\
\hline & $r V$ & ry & ro & $r \leq$ & المفردة & \\
\hline & $*,, \vee 9 \leq$ & $* *,, V \leq 7$ & $* *, \lambda r \varepsilon$ & $* *, V Y T$ & معامل الارتباط & \\
\hline
\end{tabular}

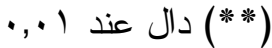

من خلال النتائج التى أسفرت عنها معاملات الارتباط، يتضح أن جميـع

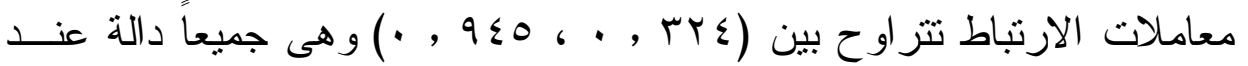
مستوى 0 . , . ، . , . ، وبالتالى فإن أسئلة المقياس تتجه لقياس درجة كل مهارة من المهار ات الرئيسة لمقياس التفاعل الاجتماعى المصور . ولتحديد مدى اتساق درجات المهار ات الرئيسة، و الارجة الكليـــة لمقيــاس التقاعل الاجتماعى المصور، تم حساب معاملات الارتباط بين درجة كل مهـارة رئيسة، و الدرجة الكلية للمقياس، ويوضح جدول (7) قيم معاملات الارتباط بــين درجة كل مهارة رئيسة، و الدرجة الكلية لمقياس التفاعل الاجتماعى المصور : 
جدول (†) معاملات الارتباط بين درجة كل مهارة رئيسة مع الارجة الكلية للمقياس

\begin{tabular}{|c|c|c|}
\hline مستوى الدالاة & معامل الارتباط بالنسبة & المهارات الرئيسة بمقياس التفاعل \\
\hline$\cdot, \cdot 1$ & r & التعاون \\
\hline., .0 & $*,\{\leqslant 70$ & حب الآخرين \\
\hline$\cdot, \cdot, 1$ & $* *, T \leqslant 7$ & آداب الحوار \\
\hline
\end{tabular}

من خلال النتائج الني أسفرت عنها معاملات الارتباط، يتضح أنها جميعـاً

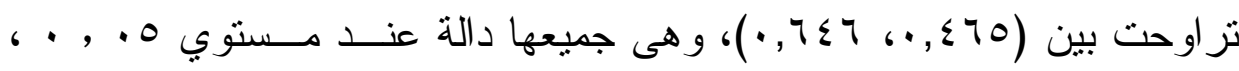

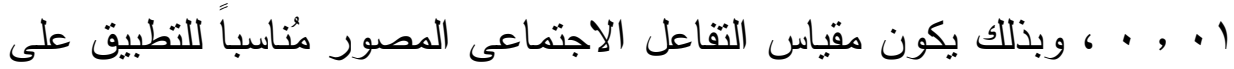

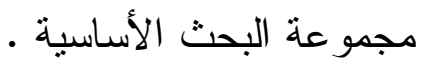
ب-حساب الثبات لمقياس التفاعل الاجتماعى المصور : يُقصد بثبات المقياس أن يُعطى المقياس نفس النتائج تقريباً إذا مـــا أعيـــ

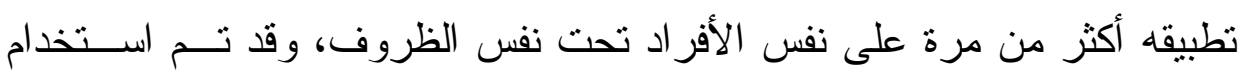

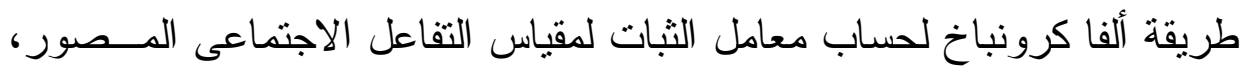

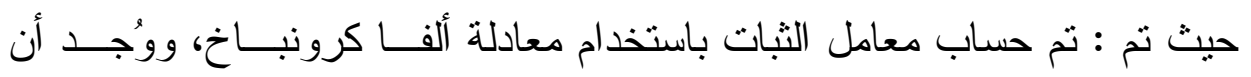

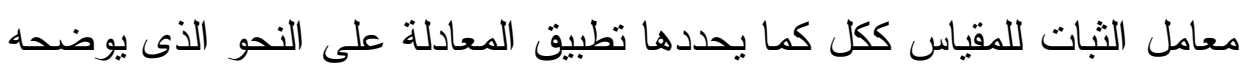
جدول (v) : (v) 
جدول (V)" معامل ثبات (ألفا كرونباخ) لمقياس التفاعل الاجتماعى المصور "

\begin{tabular}{|c|c|c|c|c|c|}
\hline معامل ثبات ألفا & التباين & $\varepsilon$ & p & ن & المهار بات المتضمنة \\
\hline$\cdot, \vee \vee \leqslant$. & $9,0 \mathrm{~V}$ & $r, .9$ & 9,10 & 9 & التعاون \\
\hline$\cdot, \vee \vee 74$ & $\vee, 7 \Lambda$ & $r, V Y$ & $\varepsilon, 7$. & 9 & حب الآخرين \\
\hline$\cdot, \vee \vee \vee 1$ & rT,qT & $0, \lambda r$ & $11,9 \pi$ & 9 & آداب الحوار \\
\hline$\cdot, \wedge \vee 0$ & $110, Y r$ & $1 \cdot, v r$ & rA, \&. & rV & المقياس ككل \\
\hline
\end{tabular}

يتضـح من الجدول السابق أن قيمة معامل الثبات كما أسفر عنهـــا تطبيــق

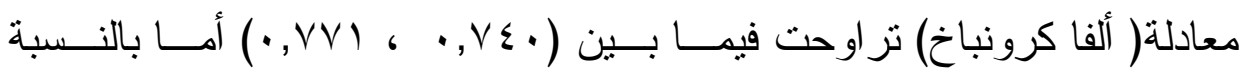
للمقياس ككل فقد بلغت ( NV0 , • ) وهى قيمة مرتفعة، وهذا يُعد ثبات المقياس قيد البحث. ج) حساب درجة و اقعية المقياس : تحدد درجة الو اقعية للعبار ات بمدى تطابق الموقف المثير مــع الموقـف الذى يعيشه الطفل، وتستخدم معادلة هوفستاتر Hofstaetter لقياس مدى و اقعية العبارة الخاصة بالمقياس • مدى و اقعية العبارة = (((مج س+) + (مج س-)) / (مج س •)) (كمال زيتــون، (ON : : . . 9

(مج س+) = مجموع استجابات مو افق ، (مج س -) = مجموع اســتجابات

$$
\text { غير مو افق }
$$

(مج س · ) = مجموع استجابات غير متأكد

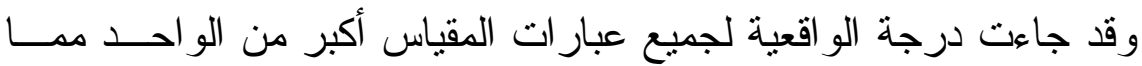
يثير إلى و اقعية العبار ات و الجدول التالى جدول (^) يوضح ذلك : 


\section{جدول (^) "}

درجة الواقعية لكل عبارة بمقياس التفاعل الاجتماعى المصور "

\begin{tabular}{|c|c|c|c|c|c|c|c|}
\hline v & 7 & 0 & $\varepsilon$ & $r$ & $r$ & 1 & العبارة \\
\hline$r, 0$ & $r, r \leq$ & $r, q q$ & $r, \leqslant 0$ & $r, r \leq$ & $r, 0$ & $\{, \varepsilon 1$ & درجة الواقعية \\
\hline $1 \leq$ & Ir & Ir & 11 & 1. & 9 & $\wedge$ & العبارة \\
\hline$r, 0$ & $r, I \leq$ & $r, Y \varepsilon$ & $r, 0$ & $r, 99$ & $r, 9 q$ & $r, r \leq$ & درجة الواقعية \\
\hline$r_{1}$ & $r$. & 19 & 11 & iv & 17 & 10 & العبارة \\
\hline \multirow[t]{3}{*}{$\varepsilon, \varepsilon 1$} & $r, \wedge q$ & $\varepsilon, \varepsilon)$ & $r, 0$ & $0, r$ & $\varepsilon, \varepsilon 1$ & $\varepsilon, \varepsilon 1$ & درجة الواقعية \\
\hline & TV & Y & ro & $r \leq$ & r & rr & العبارة \\
\hline & $\{, \varepsilon 1$ & $r, \wedge q$ & $1,0 \leqslant$ & 1,91 & $\{, \varepsilon 1$ & $\{, \varepsilon 1$ & درجة الواقعية \\
\hline
\end{tabular}

د) تحديد الزمن اللازم لأداء مقياس مهارات التفاعل الاجتماعى المصور :

تم تحديد الزمن اللازم للإجابة عن المقياس؛ بتسجيل الزمن الذى استغرقه كل طفل فى مجموعة البحث الاستطلاعية و عددهم( • طفل) لإنهاء الإجابة عن عبار ات المقياس ثم حساب منوسط مجموع تلك الأزمنة.

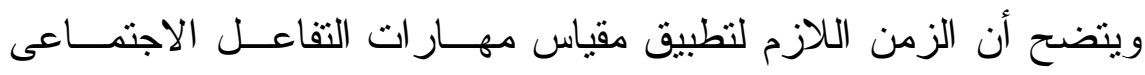
المصور هو (•ـ) دقيقة، وقد روعي الالتز ام بهــذا الــزمن قــدر المـستطاع عند التطبيقين (القبلى و البعدى) لمقياس مهار ات التفاعل الاجتـــاعى المـصور

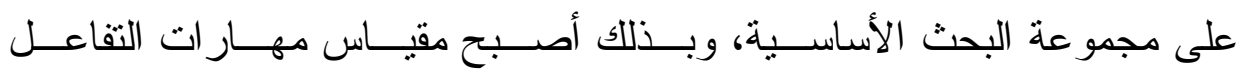

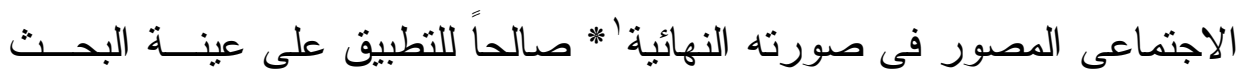
• الأساسية

(**) ملحق (ץ) : مقياس مهارات التفاعل الاجتماعي المصور لطقل الروضة . . 
ا ـ الهوف من الدراسة التجريبية للبحث :

يتمنل الهدف من الدر اسة التجريبية للار اسة الحالية فى التعرف على مدى فاعلية برنامج مقترح قائم على الأنشطة الغنائية فى تتمية التقاعـلـل الاجتمــــى لاى طفل الروضة.

\section{r. منهج البحث المستخدم بالار اسة :}

اعتمد البحث الحالى على منهجين بحثين هما :

1- المنهج الوصفى التحليلى فى تحديد الإطار النظرى للبحث، و إكساب أطفال الروضة مهار ات التفاعل الاجتماعى وتحديد أهم المهار ات الرئيسة للتفاعل الاجتماعى المناسب تتميتها لدى طفل الروضة (عينة البحث)، وبناء أدوات

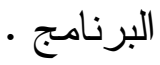

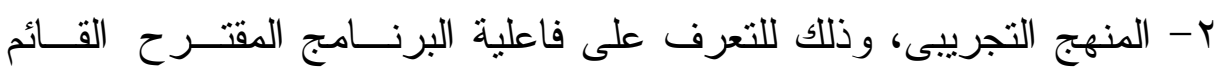

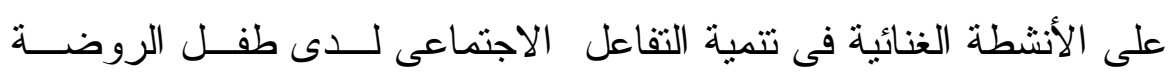

$$
\text { بالأردن }
$$

r. متغير ات تجربة البحث : وتتحدد فى المتغيرات التالية : أ. المتغير المستقل : تطبيق البرنامج المقترح القائم على الأنشطة الغنائية. ب. المتغير التابع : مهار ات التفاعل الاجتماعى لاى طفل الروضة. ع. التصميم التجريبى للبحث :

اعتمدت الدر اسة الحالية على تصميم المعالجات التجريبية القبلية و البعدية، وذللك من خلال مجمو عتين تجريبية وضابطة، ويوضح الشكل التــالى التـصميم

$$
\text { التجريبى للبحث : }
$$




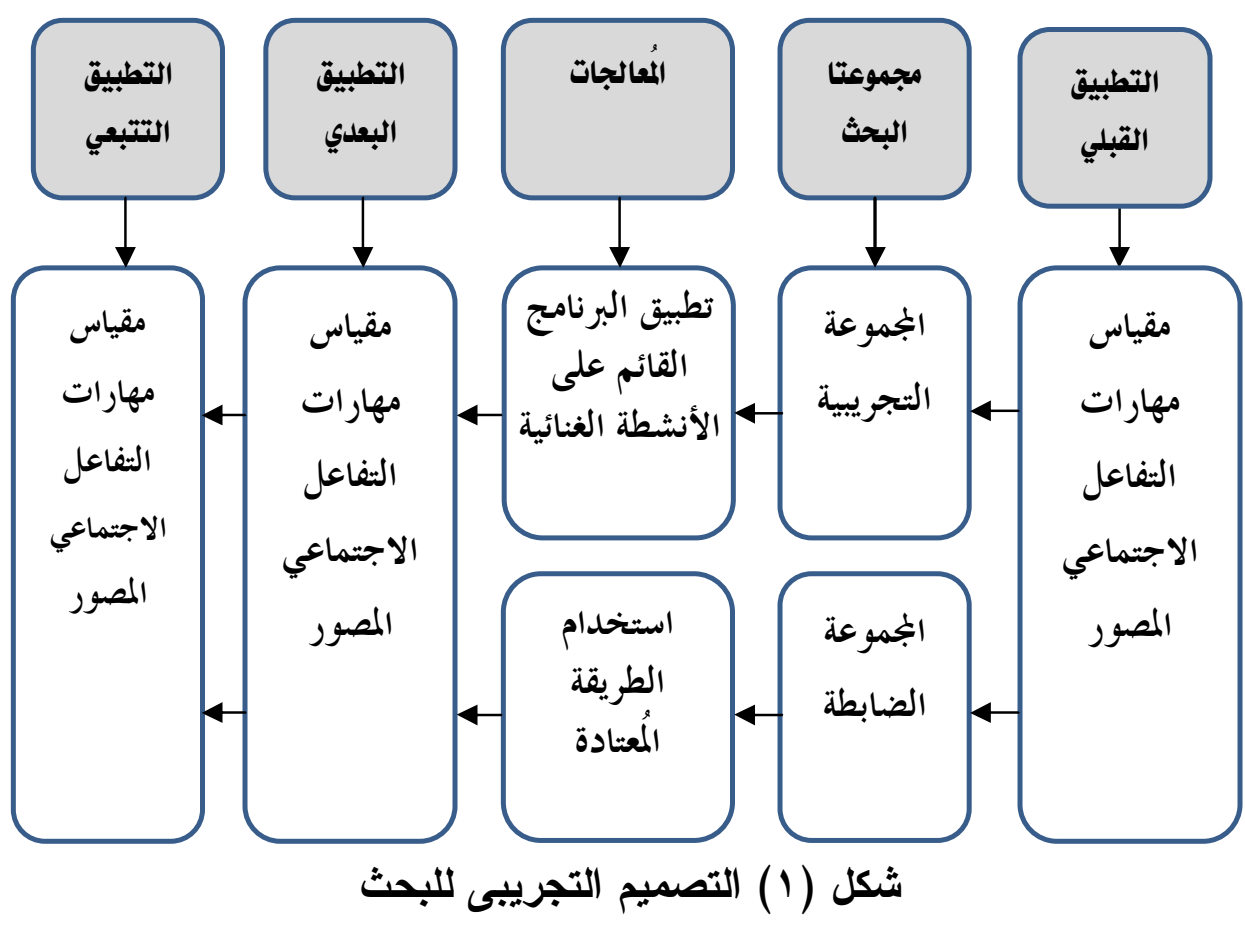

هـ اختيار عينة البحث التجريبية :

تم اختيار عينة من أطفال الروضة (المستوى الثانى) وتم تقسيم الأطفــال

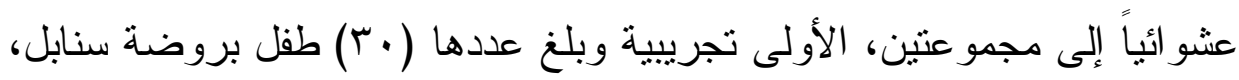

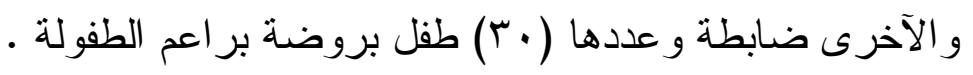

צ. تطبيق أدوات البحث قبلياً :

تم تطبيق مقياس التقاعل الاجتماعى المصور على أطفــال المجــــوعتين

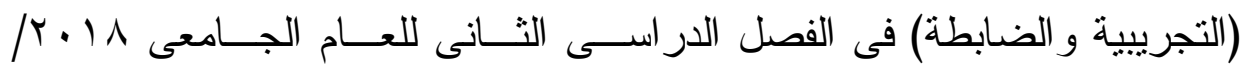

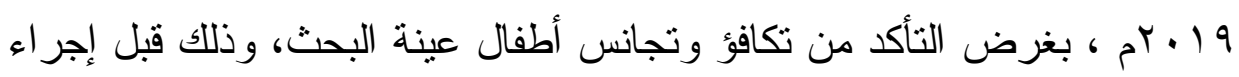

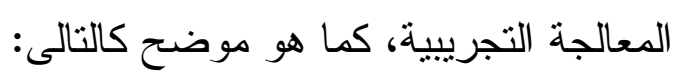


- التأكد من تكافؤ المجموعتين فى مقياس التفاعل الاجتماعى المصور قبلياً : تم استخدام معادلة "ت" لمجموعتين غير مرتبطنتين؛ لبحث دلالة الفــروق بين متوسطي درجات كل من المجموعة التجريبية و الضابطة فى مقياس التفاعل الاجتماعى المصور ككل قبلياً، و الجدول (9) يوضح نلك النتائج :

\section{جدول (a)}

قيمة "ت" ودلالتها الإحصائية للفروق بين متوسطي درجات كل من المجموعة التجريبية والمجموعة الضابطة في مقياس التفاعل الاجتماعى المصور قبلياً

\begin{tabular}{|c|c|c|c|c|c|c|c|c|}
\hline مستوى & الالالة & ت & د. د. & $\varepsilon$ & م & ن & |لبحث & مقياس التفاعل \\
\hline غير دالة & D Tr & $\cdot, \leqslant 97$ & 01 & $\varepsilon, \cdot V$ & $r v, 1 r$ & $r$. & ت & المقياس الكلى \\
\hline & & & & $r, \nu \leq$ & אז,דיץ & r. & ض & \\
\hline
\end{tabular}

يتضـح من الجدول السابق عدم وجود فــروق ذو دلالـــة إحــصائية بــين متوسطي درجات المجموعة التجريبية و المجمو عة الضـابطة في مقياس التفاعـلـ الاجتماعى ككل؛ حيث جاءت جميع قيم "ت" أقل من القيمة الجدولية حيــث "ت "

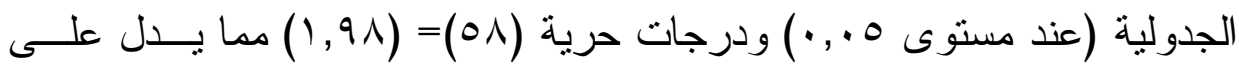
تكافؤ المجمو عتين فى مقياس التفاعل الاجتماعى المصور القبلى. V. الخطة الزمنية لتطبيق تجربة البحث :

لتحديد الخطة الزمنية لتدريس البرنامج المقترح، و الذى بلغ عدد المهار ات الرئيسة المتضمنة به (r) مهار ات و عدد الأنشطة (YV) نشاط غنائي، تم تطبيق تلك الأنشطة بو اقع r أنشطة أسبو عياً، استغرق تطبيق كل نـشاط ( • 9) دقيقــة، وفى ضوء ذلك اتضحت الخطة الزمنية لتطبيق تجربة البحث . 
^. التطبيق البعدى لأداة البحث :

عقب الانتهاء من تطبيق البرنامج على المجموعة التجريبية، تــم تطبيــق

أداة البحث المتمثلة فى مقياس مهار ات التقاعل الاجتماعى المصور بعدياً علـى الـى

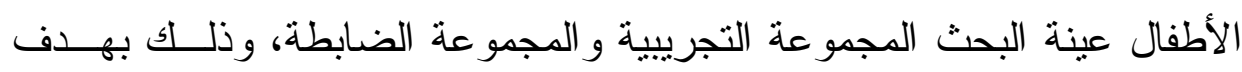

تحديد الدرجة الكلية البعدية لأداء الأطفال عينة البحث على المقياس المصور . رابعاً : نتائج الار اسة التجريبية : • النتائج الخاصة بمقياس مهار ات التفاعل الاجتماعى المصور : للتحقق من صحة الفرض الأول الذى ينص على : " توجد فروق ذو دلالــة إحسـصائية بـين متوســى درجــات أطفــال

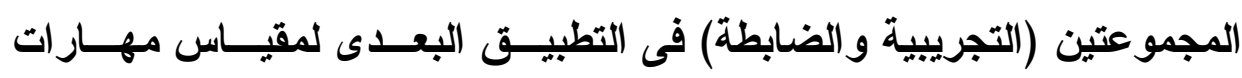
التفاعل الاجتماعى لصالح المجموعة التجريبية " . تم استخدام معادلة " ت" لمجموعتين غير مرتبطتين؛ لبحث دلالة الفــروق بين متوسط درجات كل من المجموعة التجرييية و المجمو عة الضابطة فى أبعـاد

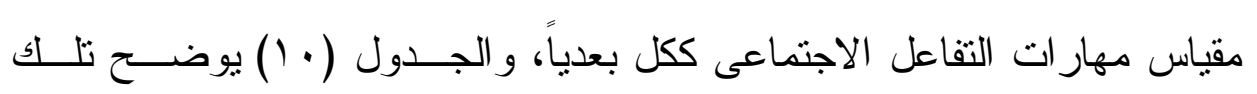
النتائج : (1)

جدول (• 1) قيمة "ت" ودلالتها الإحصائية للفروق بين متوسطى درجات كل من

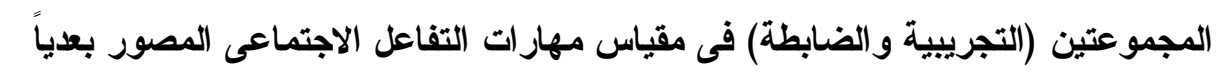

\begin{tabular}{|c|c|c|c|c|c|c|c|}
\hline مستوى & 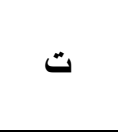 & ح.د & $\varepsilon$ & p & ن & مجموعتا & مقياس التفاعل \\
\hline \multirow[t]{2}{*}{ دالة } & $1 \cdot, V T$ & $0 \wedge$ & $0, .9$ & $\Sigma 1, \wedge \mu$ & $r$. & ت & المقياس \\
\hline & & & $7, \cdot \varepsilon$ & $r \neg, r V$ & $r$. & ض & الكلي \\
\hline
\end{tabular}


يتضح من الجدول السابق وجود فروق ذو دلالة إحصائية بين متوســـي

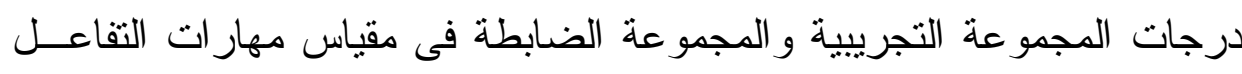

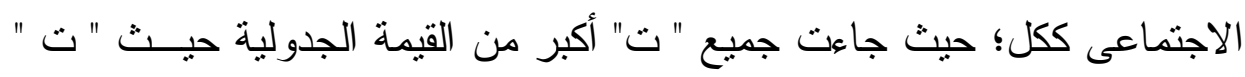

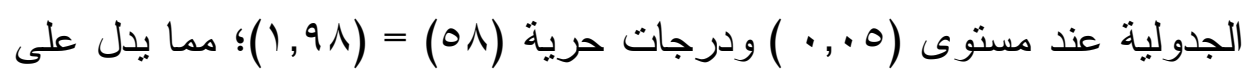

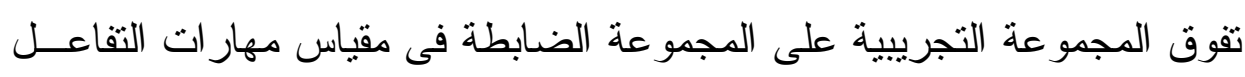

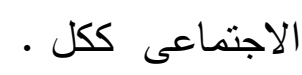

وفى ضوء تلأك النتيجة، يمكن قبول الفرض الأول من فــروض البحــث وهو:

" توجد فروق ذو دلاة إحصائية عند مستوي دلالة ه ., . بين متوسطى

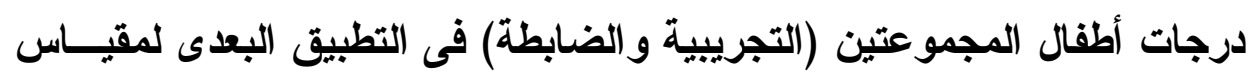

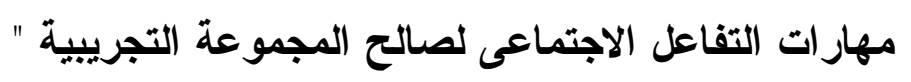
• مقارنة نتائج التطبيق القبلى بالبعدى للمجموعة التجريبية فى نتائج مقياس

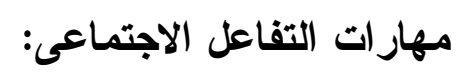
و لاختبار صحة الفرض الثانى الذى ينص على :

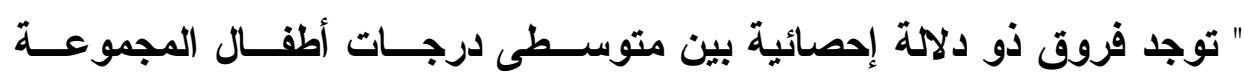

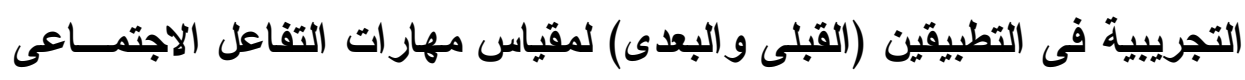
لصالح التطبيق البعدى " . تم استخدام معادلة "ت" للمجموعات المرتبطة لبحث دلالة الفـروق بــين

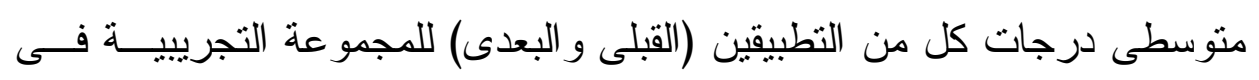

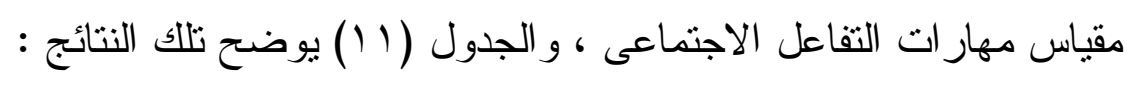




$$
\text { جلول (11) }
$$

قيمة "ت" ودلالتها الإحصائية للفروق بين متوسطى درجات

كل من التطبيقين (القبلى و البعدى) للمجموعة التجريبية في مقياس

\begin{tabular}{|c|c|c|c|c|c|c|c|}
\hline \multicolumn{8}{|c|}{ مهارات التفاعل الاجتماعى } \\
\hline مستوى الدلالة & 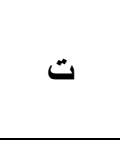 & ح.د & $\varepsilon$ & $p$ & ن & القياس & مقياس التفاعل \\
\hline \multirow{2}{*}{ دالة } & $1 Y, 70$ & rq & $0, .9$ & $\sum 1, \lambda r$ & $r$. & بعدى & \multirow{2}{*}{ المقياس الكلي } \\
\hline & & & $\varepsilon, \cdot \vee$ & $r v, I T$ & $r$. & 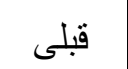 & \\
\hline
\end{tabular}

يتضح من الجدول الــسابق وجــود فـروق ذو دلالــة إحــصائية بـين متوسطى درجات التطبيقين (القبلى و البعدى) فى المجموعة التجريبية فى مقياس

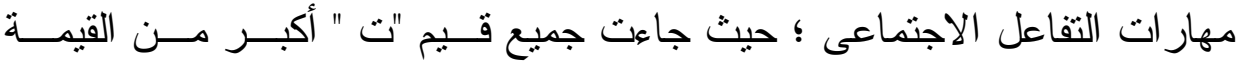

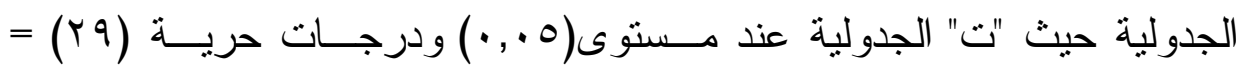

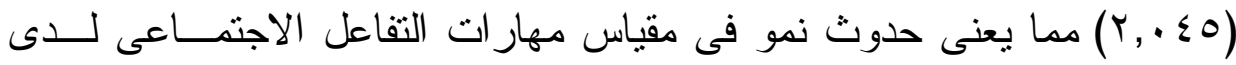

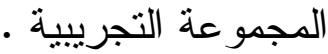

وفى ضوء تلاك النتائج، يمكن قبول الفرض الثـانى مـن فـروض البحــث

" توجد فروق ذو دلالة إحصائية عند مستوى (ه ., ·) بـين متوسـطى

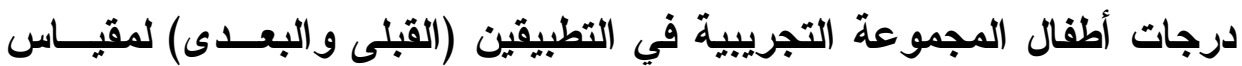

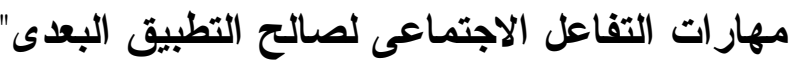


• فاعلية المعالجة التجريبية فى تنمية مهارات التفاعل الاجتماعى :

(حجم التأثير) : (حس)

لتحديد فاعلية المعالجة التجريبية فى تتمية مهار ات التفاعـلـل الاجتمـــى،

و لاختبار صحة الفرض الثالث من فروض البحث وهو :

" يحقق تطبيق البرنامج المقترح فاعلية كبيرة باســتخدام مربــع إيتــا

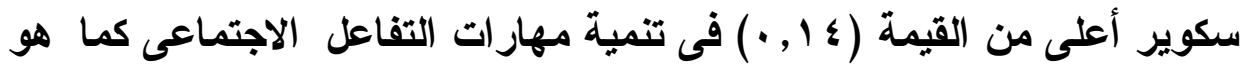

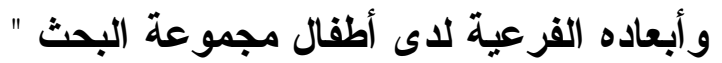

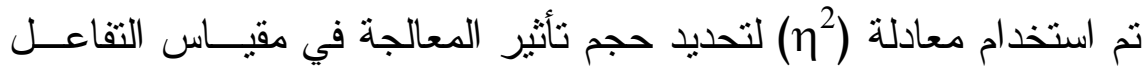
الاجتماعى ككل، اعتماداً على قيمة "ت" المحسوبة عند تحديد دلالة الفروق بـين

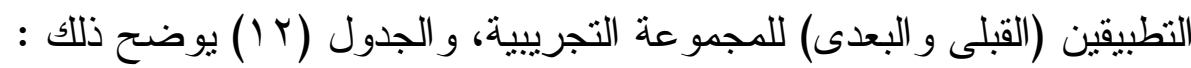

$$
\text { جدول (r) }
$$

قيمة ( ) وحجم تأثير المعالجة التجريبية فى تنمية

\begin{tabular}{|c|c|c|c|}
\hline \multicolumn{4}{|c|}{ مقياس مهارات التقاعل الاجتماعى } \\
\hline حجم التأثير & $\eta^{2}$ & 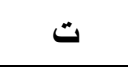 & مقياس التفاعل الاجتماعى \\
\hline كبير & $\cdot, 10$ & $1 \%, 70$ & المقياس الكلي \\
\hline
\end{tabular}

يتضح من الجدول السابق أن قيمة $\eta^{2}$ لمقياس مهار ات التقاعل الاجتماعى الكلي بلغت (10, •) ؛ مما يعنى أن المعالجة التجرييية تسهم فى التباين الحسادث فى مقياس مهار ات التفاعل الاجتماعى بنسبة 110\% ، مما يـلـل علــى فاعليــة

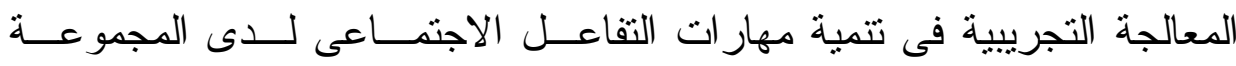

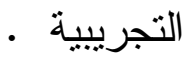

المجلد الخامس




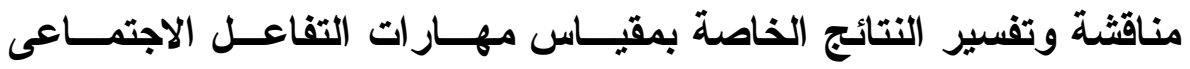

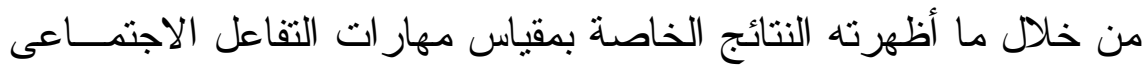

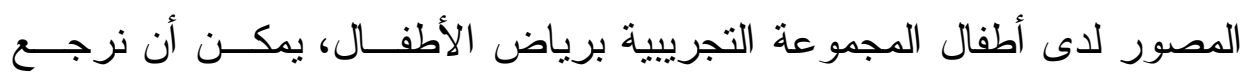

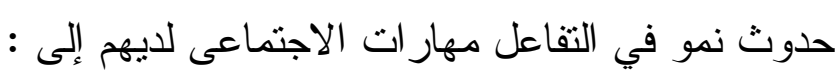

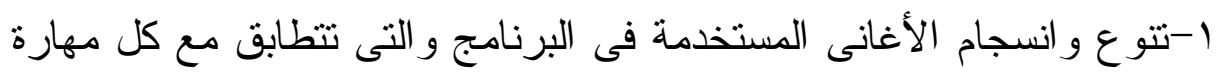

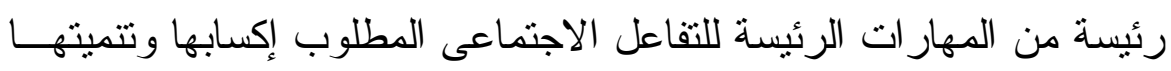

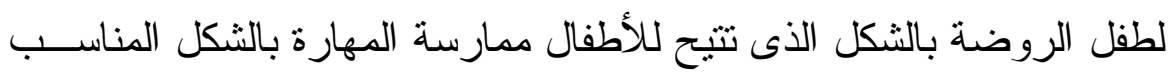

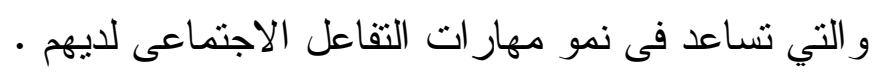

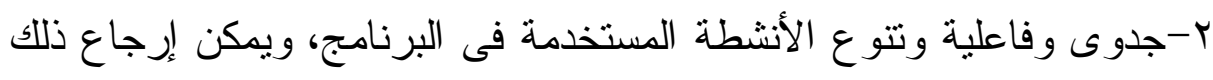

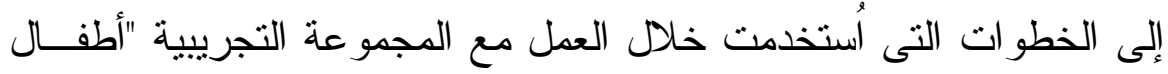
الروضة" من حيث تكر ار الأغانى فى النشاط الواحد و التى تستثير إيجابيــة

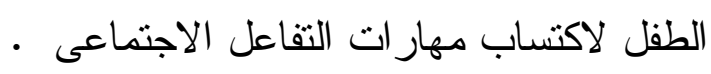
r- طرح الأسئلة المثيرة للتفكير اثثاء كل نشاط على الأطفال، و هذه الأســئلة

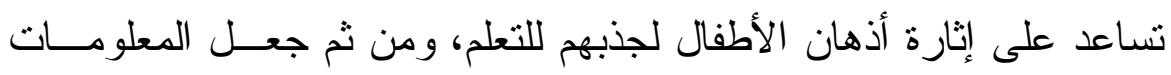

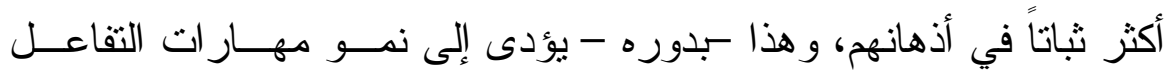

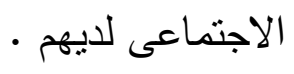

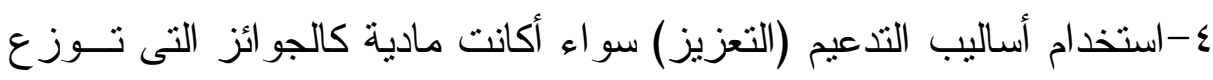

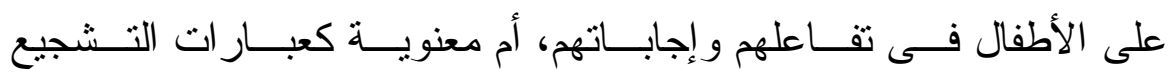

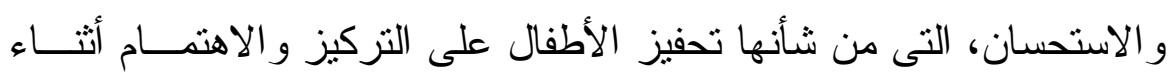

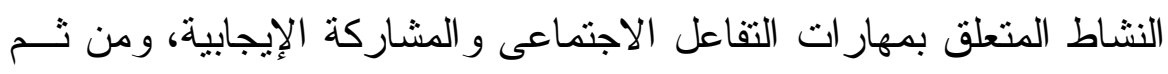
ارتفاع مستوى نمو قيم التفاعل الاجتماعى لديهم . 
• مقارنة نتائج التطبيق البعدى بالتتبعى للمجموعة التجريبية فـى مقيــاس

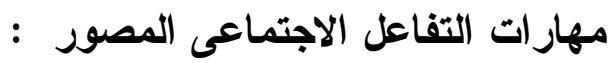

$$
\text { و لاختبار صحة الفرض الر ابع الذى ينص على : }
$$

" لا توجد فروق ذو دلالة إحسصائية بـين متوسـطى درجـات تلاميــذ المجموعة التجريبية فى التطبيقين (البعدى والتتبعى) لمقياس مهارات التفاعل

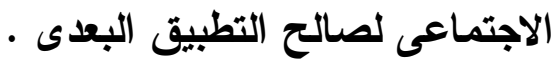
تم استخدام معادلة "ت" للمجموعات المرتبطة لبحث دلالة الفـروق بــين

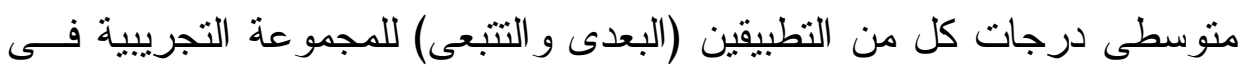

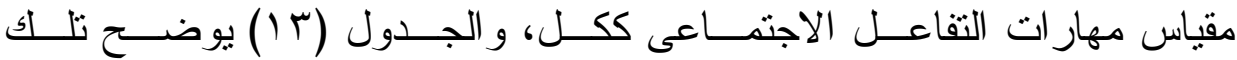

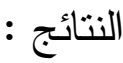

$$
\text { جلول (1) }
$$

قيمة "ت" ودلاتها الإحصائية للفروق بين متوسطى درجات كل من التطبيقين

\begin{tabular}{|c|c|c|c|c|c|c|c|c|}
\hline مستوى & الدلالة & 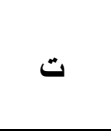 & 2.د & $\varepsilon$ & P & ن & القياس & مقياس الاجتفاعل \\
\hline غير دالة &., 010 & $\cdot, v \cdot A$ & rq & $0, .9$ & $\sum 1, \Delta r$ & $r$. & بعدى & المقياس \\
\hline & & & & $\varepsilon, 91$ & $\varepsilon 1, \vee q$ & $r$. & تتبعى & أكلي \\
\hline
\end{tabular}
(البعدى و التبعى) للمجموعة التجريبية فى مقياس مهارات التفاعل الاجتماعى

يتضح من الجدول السابق عدم وجود فــروق ذو دلالـــة إحــصائية بــين

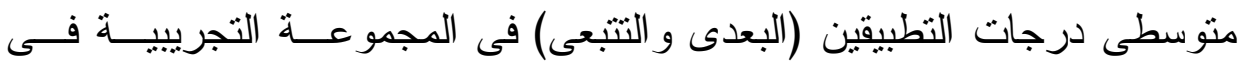
مقياس مهار ات التفاعل الاجتماعى ككل ؛ حيث جاءت جميع قيم "ت " أكبر مسن

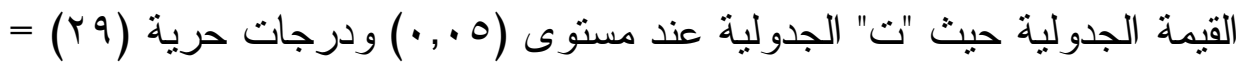




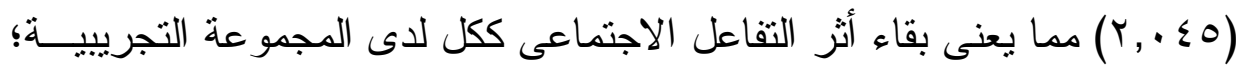

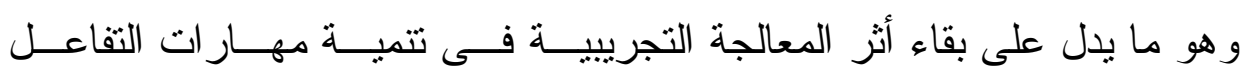
الاجتماعى لدى الأطفال.

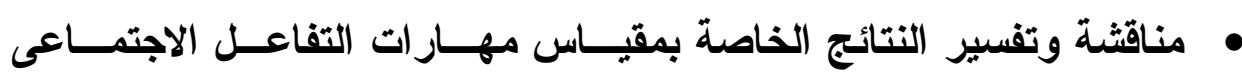
المصور:

وتتفق نتائج البحث مع در اسة كلّ من : در اسة (نبر اس يـونس، ؛ . . ب)

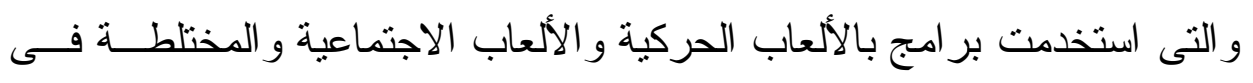
تتمية التفاعل الاجتماعى لدى أطفال الرياض بعدــر (0-7) ســنوات، ودر اســـة

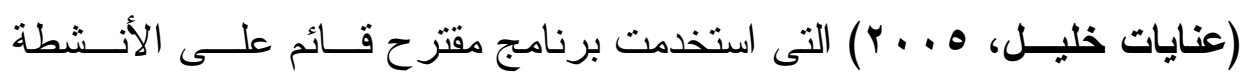
الموسيقية لإكساب بعض القيم السلوكية لدى تلاميذ المرحلة الابتدائية، ودر اســـة

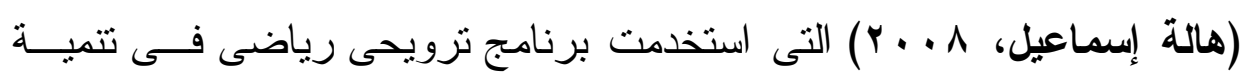

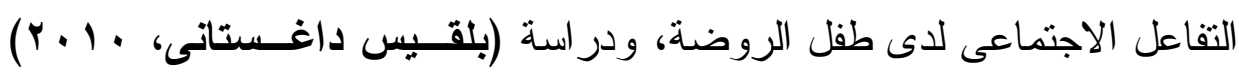
و التىى استخدمت برنامج قائم على الأنشطة التربوية لتتمية بعض القــيم الخلقيــة

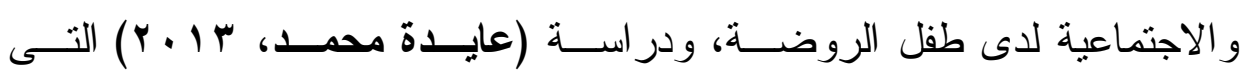
استخدمت برنامج تدريبى فــى تتميــة المـسؤولية الاجتماعيــة لــدى أطفــال

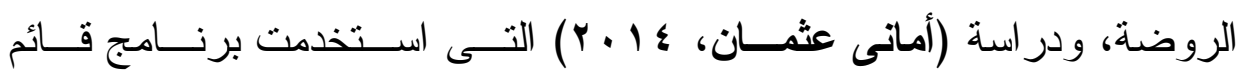
على إستر اتيجيات الألعاب الحركية لتتمية بعض المهار ات الحركيــة الأساســية

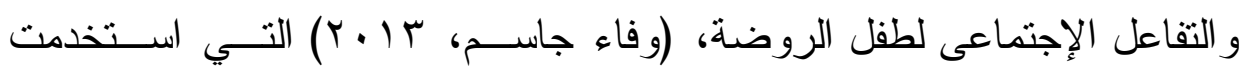
برنامج تدريبي يقوم بالموسيقى في تتمية السلوك الاجتماعي المرغوب فيه لــدى أطفال الروضة. 
ومن خلال ما أظهرته النتائج الخاصة بمقياس التفاعل الاجتماعى المصور

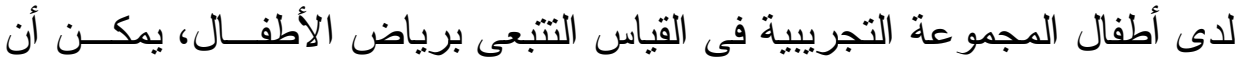

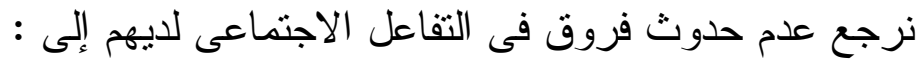

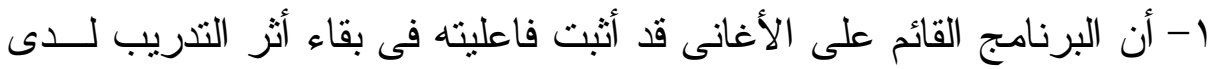

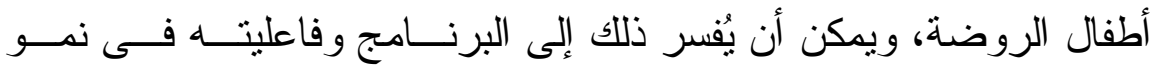
التفاعل الاجتماعى لدى أطفال الروضة فى ضوء ما تضدنه البرنامج مـن الترن فنيات واستر اتيجيات و الأنشطة المختلفة، و التى انعكس أنز ها على استخدام الأطفال لها في مو اقف حياتهم الو اقعية .

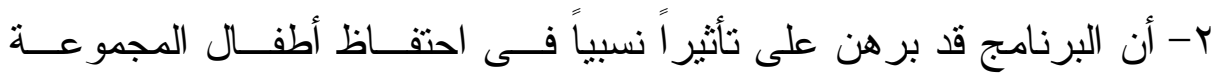

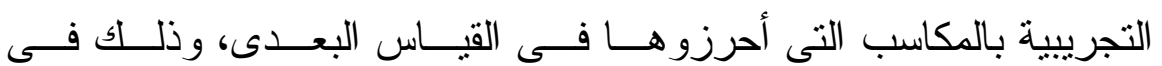
فترة القياس التتبعى بعد مرور شهر ونصف على انتهاء البرنامج، ويُفــسر

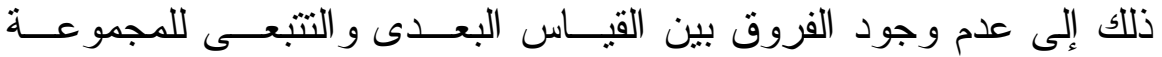

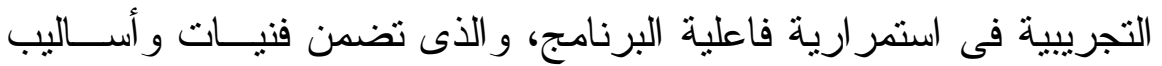

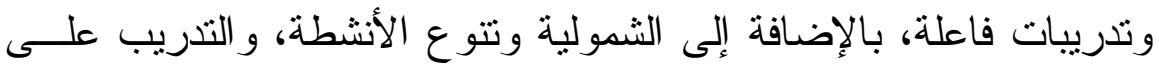

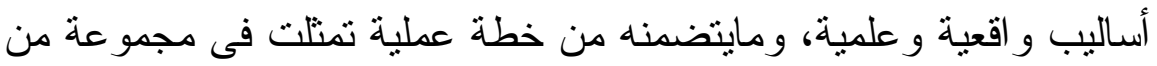

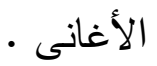

\section{توصيات البحث : - ت}

فى ضو ء ما أسفرت عنه نتائج الدر اسة، يمكن التوصية بما يلى :

1- عقد دورات تدرييية لمعلمات رياض الأطفال تتتاول ماهية الأنشطة الغنائية

التعليمية و أهميتها فى تتمية مهار ات التفاعل الاجتماعى وكيفية استـتخدامها

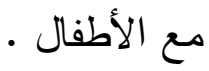


ץ- إعداد دليل لمعلمة رياض الأطفال، و الذى يساعدها على كيفيــة اســتخدام الأشطة الغنائية و الموسيقية بطريقة صحيحة .

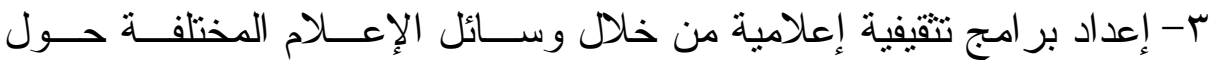

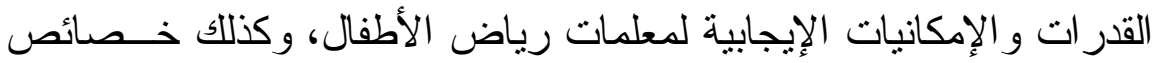

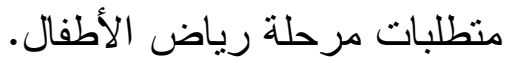
سابعاً : الدر اسات و البحوث المقترحة : 1- در اسة أثز استخدام الأنشطة الغنائية و الموسيقية علـى تتميــة الــسلوكيات

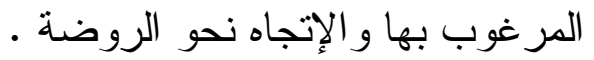
ץ- إجر اء المزيد من الدراسات التى تتتاول فعالية الأنشطة الغنائية و الموسيقية،

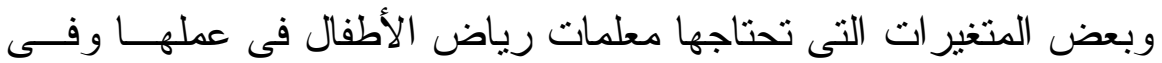
تتمية جو انب أخرى للتعلم لدى أطفال الرياض . 
1- أحمد فوزى وطارق بدر الدين • (1 . ب) : سيكولوجية الفريق الرياضى. دار الفكر العربى : القاهرة .

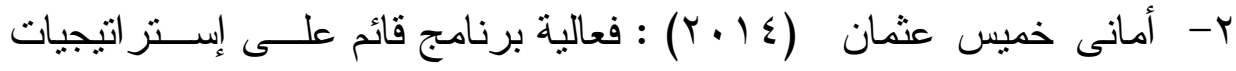

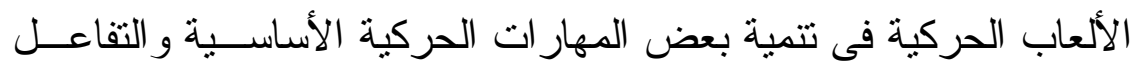

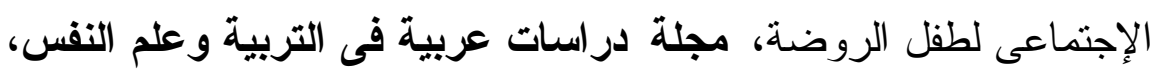

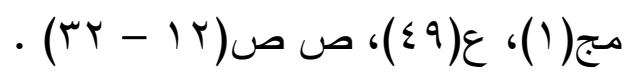

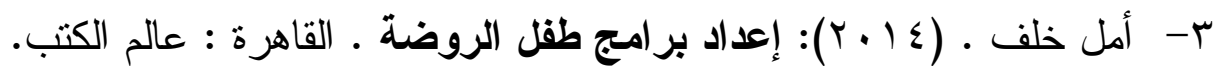

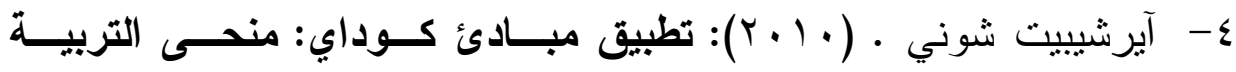

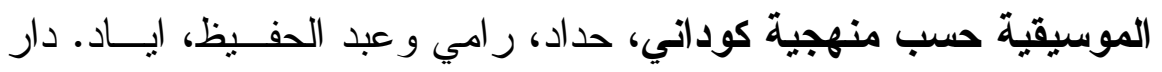

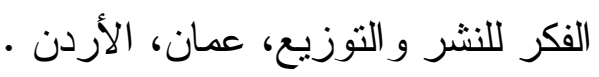

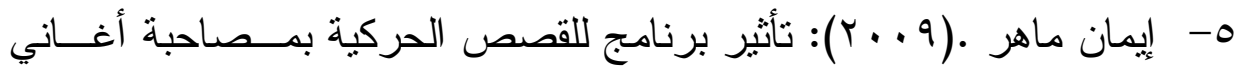

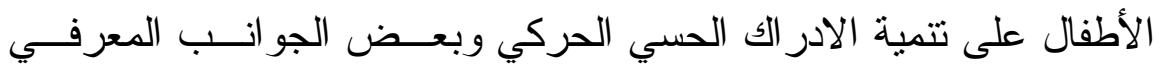

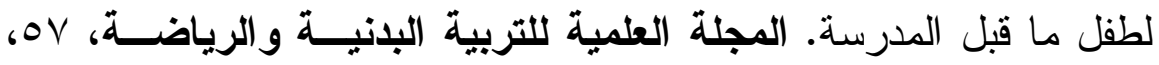

$$
. \wedge \vee-09
$$

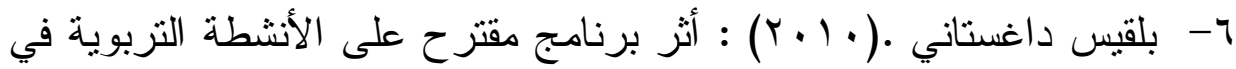

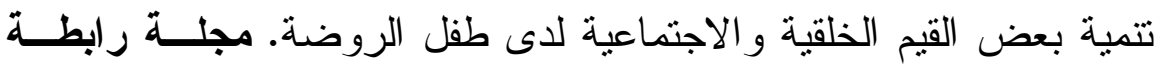

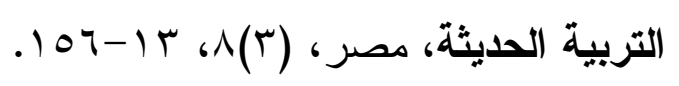

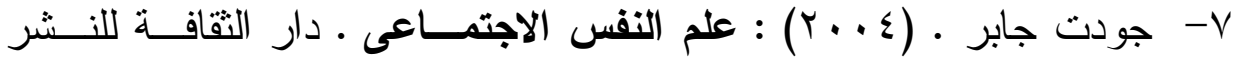
و التوزيع : عمان.

المجلد الخامس




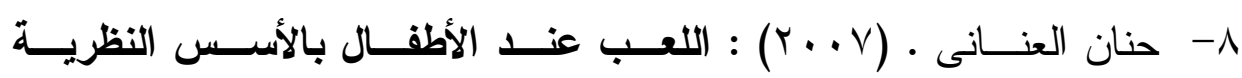

$$
\text { و التطبيقية. عمان: دار الفكر. }
$$

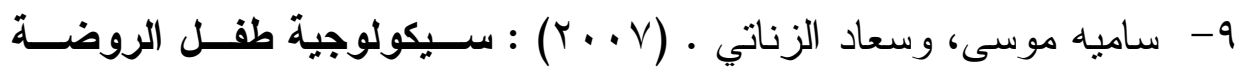

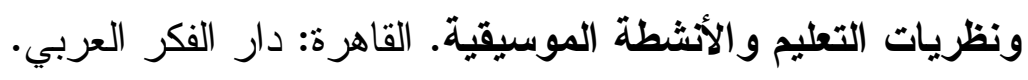

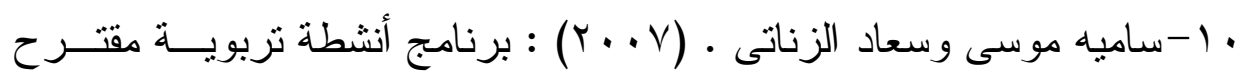

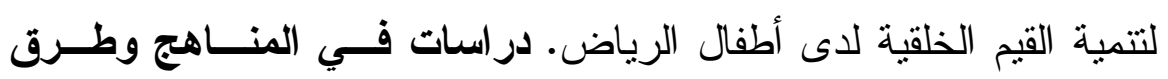

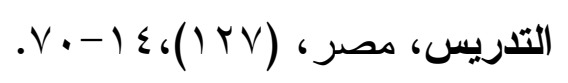

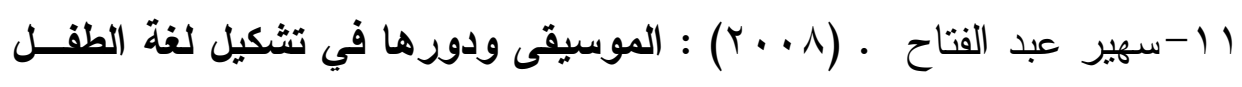

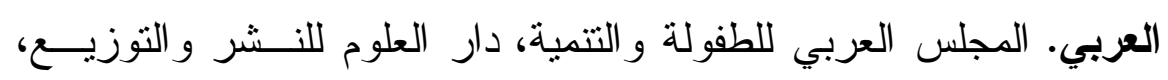
القاهرة.

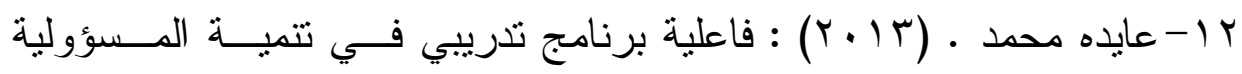

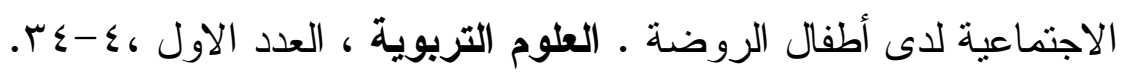

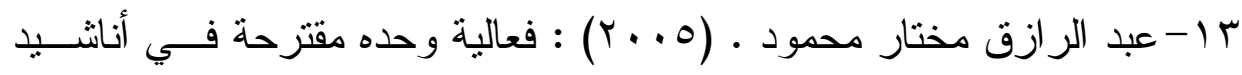

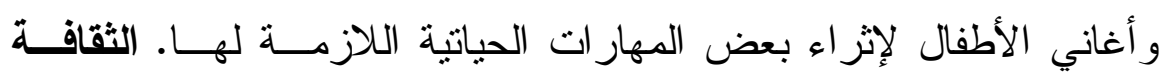

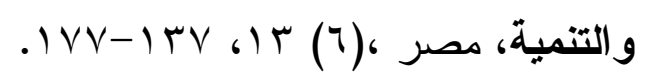

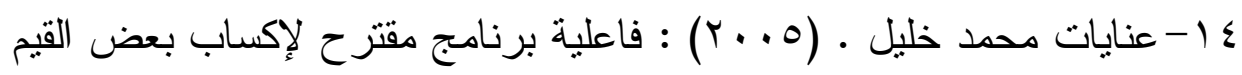

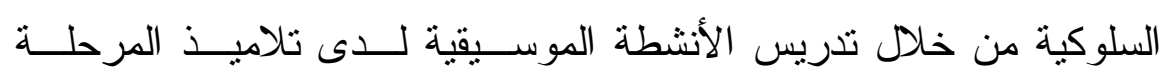

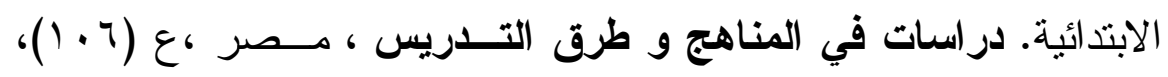

$$
.190-1 \mathrm{~V} \text {. }
$$

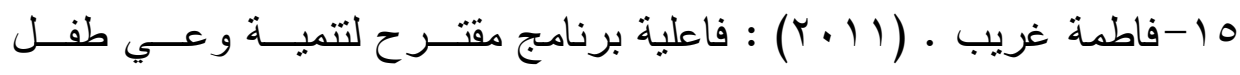

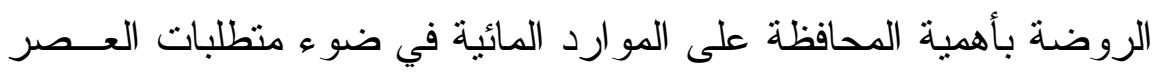


من خلال بعض الأنشطة الموسيقية والأغاني المبتكرة. المــؤتمر العلمــي

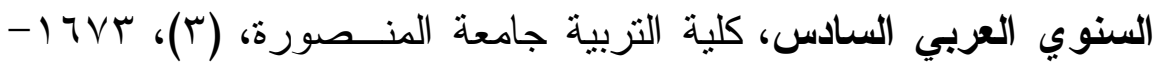
.$|V Y|$

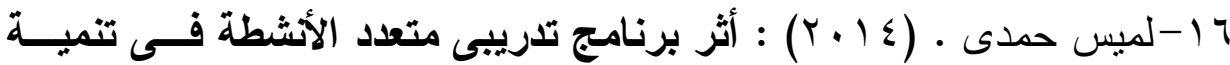
مهار ات التواصل الاجتماعى لاى أطفــال الريــاض ـ رســالة دكتــوراة منشورة ـ كلية التربية ـ جامعة دمشق .

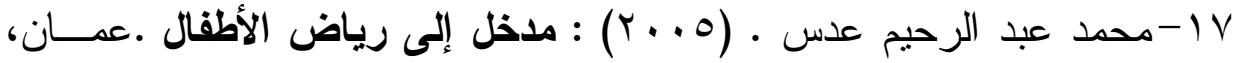

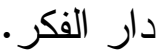

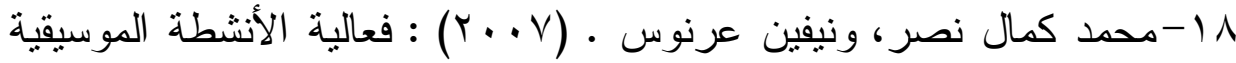
في تتمية المهار ات اللغوية لاى اطفال الروضة.المؤتمر الــسنوي، كليــة التربية النوعية بالمنصورة، الاعتماد الأكاديمي لمؤسسات وبر امج التعليم العالي النوعي في مصر و العالم العربي. 9 1 -مريم الخالدي • (^ . . ץ) : مدخل إلى رياض الأطفال .عمان: دار صــفاء للنشر و التوزيع.

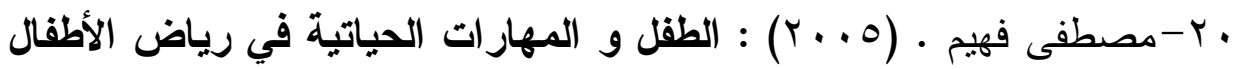
والمدرسة الابتدائية. القاهرة: دار الفكر.

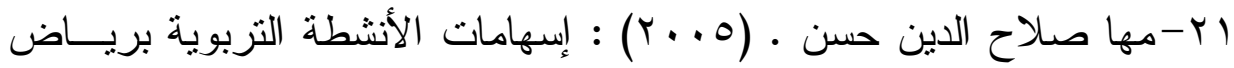

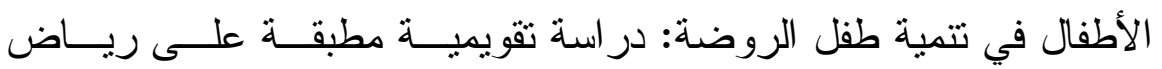
الأطفال بمحافظة القليوبية. مجلة مستقبل التربية العربية، المركز العربـي للتعليم و التتمية، (1) Y (1) 


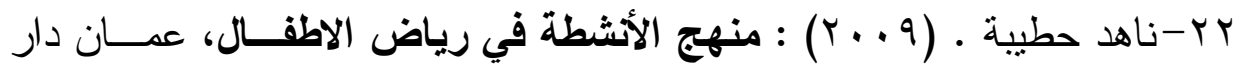
المسيرة للنشر - المن

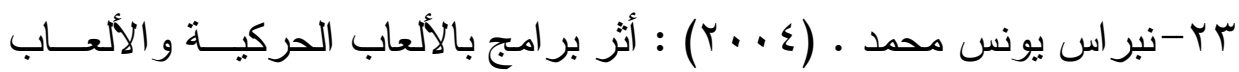

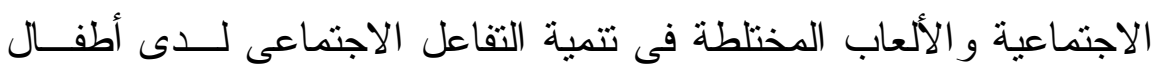

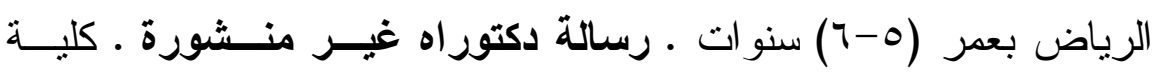

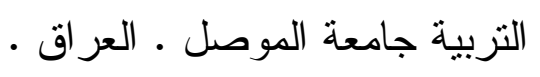

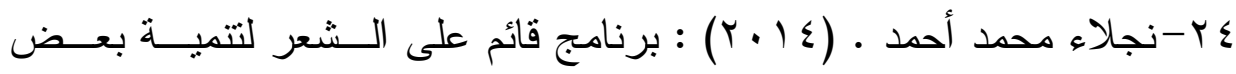

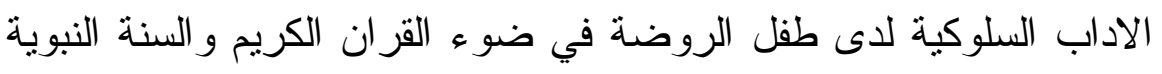

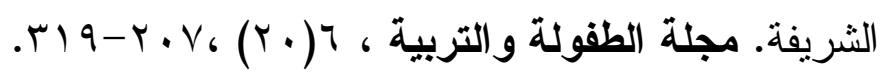

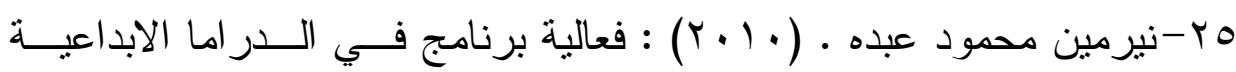

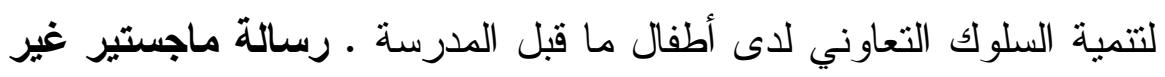
منشورة، جامعة القاهرة.

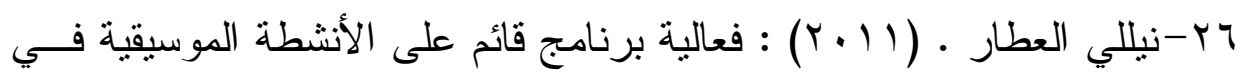

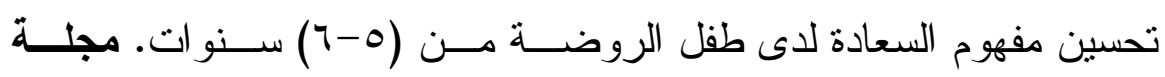

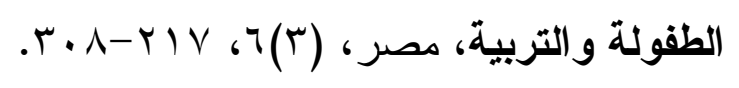

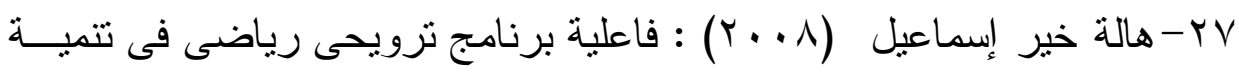

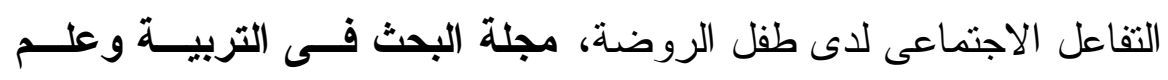

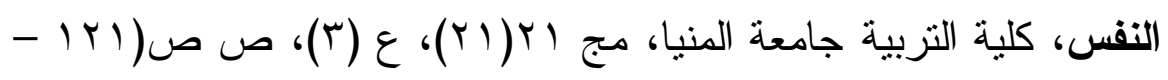
- (1)

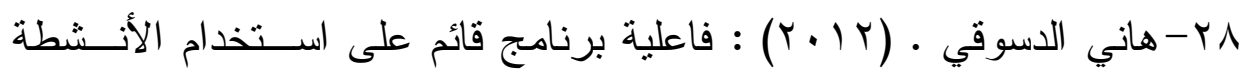

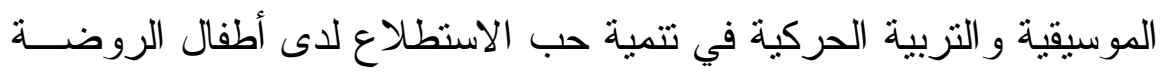


ذوي الصعوبات النمائية ــ المؤتمر العلمي الدولي الأول، كليــة التزبيــة،

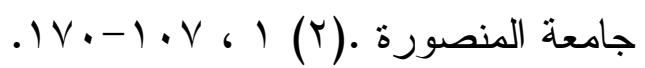

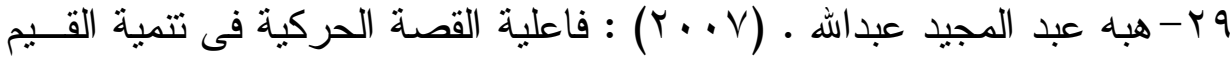

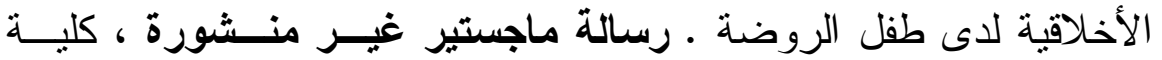

رياض الأطفال، جامعة القاهرة.

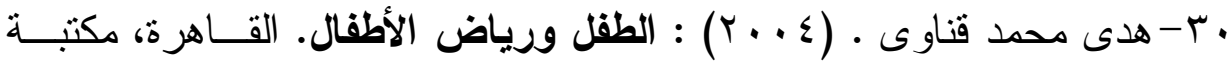

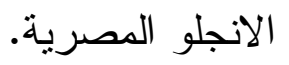

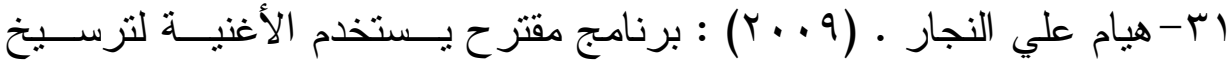

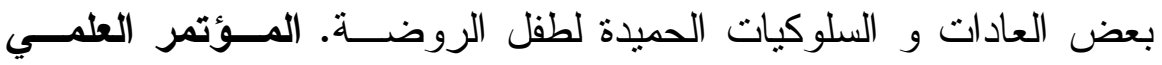

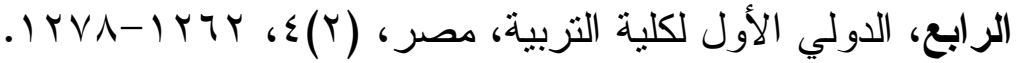

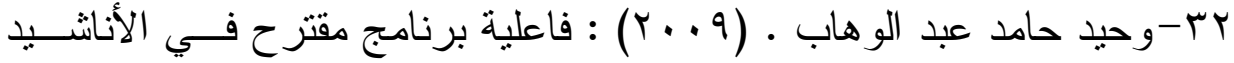

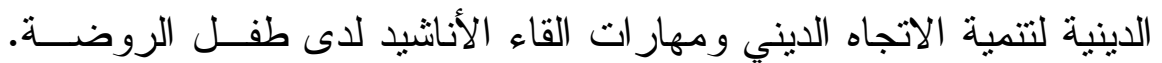

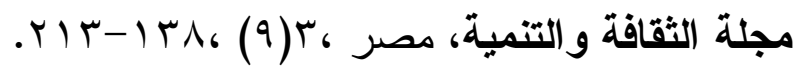

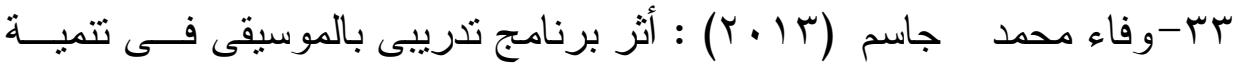

السلوك الاجتماعى المرغوب فيه لاى أطفال الحضانة ـ الجمعية العراقيــة

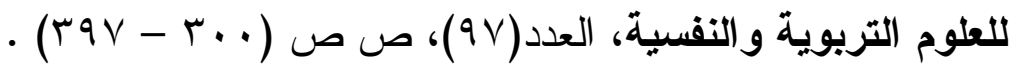

34-Augustine, $C$.(2012): How the use of music and movement impacts the learning of reading skills by preschoolers. malaysian music Journal ,4(2),55-66.

35-Catherine, S, J. (2008) : The Basic Elements of Music . Rice University, Houston, Texas Available at : http://cnx.org/content/col10218/1.7. 
36- Koringa. H . (2012) : Songs, Rhymes and Finger Plays An activity guide for under-five . Sport NZ Available at : www.sportnz.org.nz .

37- The team at Iowa State University .(2011): General Song Activities for Children's Songs. Available at : www.americanenglish.state.gov

38-Lee, L and ChuanL,S, (2015): The Impact of Music Activities on Foreign Language, English Learning for Young Children. Journal of the European Teacher Education Network, 10, 13-23.

39- Taylor, S, Morris, V, Meredith, D and Hicks,C.(2012) : Music and Movement for Young Children's Healthy Development. Dimensions of Early Childhood, 40, No 2. 32-42. 